\title{
NUEVAS APORTACIONES AL ESTUDIO DE LAS COFRADÍAS Y HERMANDADES EN LA CASTILLA BAJOMEDIEVAL: EL EJEMPLO DE JEREZ DE LA FRONTERA
}

\author{
POR \\ SILVIA MARÍA PÉREZ GONZÁlEZ \\ Universidad Pablo de Olavide (Sevilla) \\ spergon@upo.es
}

\section{RESUMEN}

El estudio de las hermandades y cofradías en el Sur de Castilla es muy amplio en lo que se refiere a los siglos posteriores a la Edad Media. En cambio durante el periodo medieval, momento en el que tienen su origen estas instituciones, las dificultades son mayores debido a la escasez de documentos. Ya estudiado el caso de Sevilla, abordamos en este trabajo el ejemplo de la segunda ciudad del Reino hispalense, Jerez de la Frontera, cuya documentación más antigua y un momento de desarrollo evolutivo anterior nos arroja nuevas luces a los aún oscuros orígenes de las cofradías y hermandades andaluzas.

PALABRAS CLAVES: Hermandades; cofradías; religiosidad popular; protocolos notariales; Andalucía medieval; economía medieval.

\section{NEW CONTRIBUTIONS TO THE STUDY OF CONFRATERNITIES AND BROTHERHOODS IN CASTILE AT THE END OF THE MIDDLE AGES: THE EXAMPLE OF JEREZ DE LA FRONTERA}

\begin{abstract}
The study of brotherhoods and confraternities in the South of Castile is very broad in the centuries after Middle Ages. But in the Middle Ages, when brotherhoods and confraternities appeared, there are lot of difficulties due to scarcity of documentation. In previous works we have already studied the example of Seville. Now we study the case of Jerez de la Frontera, the second town in the Kingdom of Seville, because in this city we can find an older documentation and a previous development, which allows us to shed light on the dark origins of these institutions.
\end{abstract}

KEY WORDS: Brotherhoods; confraternities; popular religiosity; affidavits; medieval Andalusia; medieval economy.

$\begin{array}{ll}\text { Recibido/Received } & 15-11-2013 \\ \text { Aceptado/Accepted } & 15-12-2014\end{array}$

El estudio de las hermandades y cofradías en el Reino de Sevilla, y dentro del mismo en Jerez de la Frontera, ${ }^{1}$ durante la Baja Edad Media no es un tema fácil de abordar debido a la escasez de documentación. ${ }^{2}$ Estas instituciones no han conservado su legado documental hasta fechas

1 Caro Cancela, D. (Coord.) 1999. Historia de Jerez de la Frontera. De los orígenes a la época medieval: 261-350. Cádiz: Diputación de Cádiz.

2 Un estudio sobre la producción historiográfica relativa a cofradías la encontramos en: Martín-Viveros Tajuelo, A. 2012. "Las cofradías castellanas en la Edad Media. Pasado, presente y futuro de la producción historiográfica", Espacio, Tiempo y Forma. Serie III: Historia Medieval 25: 285-307. pertenecientes a la Edad Moderna, por lo que acudir a sus archivos en busca de datos pertenecientes al periodo final de la Edad Media resulta una tarea absolutamente infructuosa. Algún conjunto documental más nutrido se conserva en los archivos eclesiásticos. Es el caso la colección de reglas de hermandades y cofradías que hace algo más de una década se publicó y que constituye una consulta obligada para el estudio del tema que nos atañe. ${ }^{3}$ Sin embargo entre estas normativas no figura ninguna perteneciente a Jerez de la Frontera. Ello hace obligatorio estudiar otro tipo de

3 Sánchez Herrero, J. y Pérez González, S.M. 2003. CXIX Reglas de cofradías y hermandades andaluzas. Siglos XIV, XV y XVI. Huelva: Servicio de Publicaciones de la Universidad de Huelva. 
documentos no conservados en instituciones vinculadas a la Iglesia, en concreto los Protocolos notariales custodiados en el Archivo municipal de Jerez de la Frontera. ${ }^{4}$

En el año 2005 publicamos un estudio sobre las cofradías y hermandades sevillanas entre 1441 y $1504 .^{5}$ En el citado trabajo analizamos casi un centenar de estas instituciones, a partir de los datos recolectados en el fondo documental constituido por los Protocolos notariales que conserva el Archivo Histórico provincial hispalense. Dado que tanto Sevilla como Jerez de la Frontera pertenecían al mismo Arzobispado, consideramos de sumo interés realizar, en la medida de lo posible, un análisis comparativo entre las cofradías y hermandades de ambas ciudades pues ello nos permitirá, entre otros aspectos, establecer puntos de convergencia, elementos de diferenciación e, incluso, determinar si en ambas localidades estas instituciones se hallaban en un mismo momento de evolución o en un tempo distinto.

La documentación que se conserva en el fondo de Protocolos notariales acerca de las cofradías jerezanas de la época que estudiamos no es muy abundante. Los motivos que explican tal escasez documental son dos fundamentalmente. En primer lugar, dado que se trata de instituciones con un carácter eminentemente religioso, la mayoría de los asuntos que requieren su puesta por escrito los van a tramitar ante autoridades eclesiásticas.

Por otra parte, recordemos que ya en esta época las cofradías contaban entre los miembros de su junta gobierno con un escribano, a quien correspondía la tramitación de una serie de negocios. La documentación relativa a estas cuestiones debió ser custodiada por las propias cofradías que la generaron. Por capítulo de regla muchas de ellas estaban obligadas a disponer de varias arcas, cuyas llaves guardaban algunos miembros de la junta de gobierno. Una de estas arcas se destinaba a la conservación de esos papeles que las hermandades producían en su actuación como una institución que funcionaba de forma independiente. Desgraciadamente, son muy pocos los casos en los que esos documentos se nos han conservado.

Estos dos motivos apuntados explican que los negocios tramitados ante los escribanos públicos, en los que las cofradías intervienen como una de las partes implicadas en ellos, no sean todo lo abundantes que cabría desear. Esta pobreza documental obliga a efectuar una exhaustiva labor de búsqueda de la información relativa a las cofradías. Es preciso leer con la mayor atención cada uno de los asientos, en busca del afortunado hallazgo de una referencia indirecta, de un dato marginal, inesperado en la mayoría de los casos, dado el carácter del documento en el que se incluye.

Algunos asuntos de índole religiosa fueron tramitados en estas escribanías públicas. Pero esta religiosidad encerrada en los protocolos notariales es una religiosidad depurada por el tamiz de lo mundano, de lo eminentemente social, que afecta a quienes intitulan esos negocios no tanto en su faceta de cristianos, miembros de la Iglesia que han de vivir de acuerdo con los mandatos por Ella establecidos, como cuanto en su vivir cotidiano, en el despliegue de las

\footnotetext{
4 Haremos referencia al mismo y al fondo documental de los Protocolos notariales con los siguientes acrónimos: AMJFPN.

5 Pérez González, S.M. 2005. Los laicos en la Sevilla bajomedieval: Sus devociones y cofradías: 115-274. Huelva: Servicio de Publicaciones de la Universidad de Huelva.
}

actividades que conforman su existencia terrenal. Al escribano llevan distintas cuestiones que requieren una solución más o menos inmediata, al margen de los tribunales y la legislación eclesiástica.

Las cofradías jerezanas de la época que estudiamos participan de esta tónica general anteriormente señalada. Las referencias a los cultos, las actividades benéfico-asistenciales, el régimen de gobierno y competencias de los miembros de la junta, el proceso de crecimiento humano, las devociones, los motivos fundacionales, las reuniones de cabildo, las cuestiones relativas a las reglas, etc., son mínimas. Pero cuando esa actividad de la cofradía supera el marco de su propio ámbito de actuación, cuando sus intereses convergen con los de personas e instituciones eminentemente sociales, y su escribano carece de las competencias que aquéllos exigen y que sólo tiene una instancia superior, el escribano público, la hermandad se ve obligada a salir de su centro de actuación, fundamentalmente el hospital, para proyectarse hacia la sociedad con la que convive.

\section{COFRADÍAS Y HERMANDADES: DEFINICIÓN Y TIPOLOGÍA}

Podemos definir la cofradía de los siglos XIII a comienzos del XVI, y del modo más general posible, como "asociación de personas, hombres y mujeres, clérigos y laicos, pertenecientes o no a una misma profesión, gremio, o estamento social que se unen para diferentes fines: piadosos, benéficos, profesionales, sociales, políticos, recreativos, penitenciales, etc., con una organización más o menos amplia y determinada y bajo la advocación de un santo patrón o protector". ${ }^{6}$

Las cofradías, siempre para la época que hemos acotado, fueron las instituciones eclesiásticas más auténticamente laicales y de laicos. ${ }^{7}$ En ellas los laicos, desde los siglos medievales, no solamente tuvieron la obligación de callar y pagar, sino que actuaron como Iglesia o como Pueblo de Dios. ${ }^{8}$

6 Para todo este tema véanse las obras de Sánchez Herrero, J. 1978. Las diócesis del Reino de León. Siglos XIV y XV. León. Colección "Fuentes y Estudios de Historia Leonesa", no 20; 1996. "El origen de las cofradías de Semana Santa o de Pasión en la Península Ibérica": Temas Medievales 6: 31-79; 1988. "Las Cofradías de Semana Santa de Sevilla durante la Modernidad. Siglos XV a XVII", en Las Cofradías de Sevilla en la Modernidad: 29-97. Sevilla: Universidad de Sevilla. 1999. "La evolución de las Hermandades y Cofradías desde sus momentos fundacionales a nuestros días" en I Congreso Internacional de Hermandades y Religiosidad Popular: 29-53. Sevilla: Fundación El Monte.

Meersseman, G.G. 1977. Ordo fraternitatis. Confraternite e pietá dei laici nel Medioevo. Roma: Herder Editrice e Librería.

8 En effet, Delaruelle et Meersseman, ont opèrè sur la plan historique la mème "revolution copernicienne" qu'avait effectuèe a l'époque sur le plan théologique un père Congar par example, c'esta-dire la redécouverte de l'Eglise comme peuple de Deu, et non pas seulement comme aorganisme hiérachique structuré. Cette intuition devait déboucher sur une prise de conscience de la place et du rôle des laïcs dans l'Eglise et dans son histoire, et je pense que ce n'est pas un hasard si le Dossier de l'ordre de la penitence au XIII' siécle, qui est l'oeuvre majeure, à mon avis, du pére Meersseman, a suivi de peu la publication des Jalons pour une théologie du laïcat. Ce qui me frappait le plus à la époque dans les travaux de père Meersseman, c'était d'abord la nouveauté de la matière. Un monde inconnu accédait, grâce a lui, á notre connaisance, ce monde des pénitens laïcs et des confréries de devotion sur lequel on ne disposait guère jusque-là de trabaux valables. Toute une partie insoupçonnée de notre histoire remontait ainsi à la surface". Vauchez, A. 1987. Les laïcs au Moyen Age. Pratiques et experiénces religieuses: 95-96. Paris: Les éditions du cerf. 
Hemos utilizado, de forma indistinta, los términos hermandad y cofradía. Por ello y para entendernos en el discurrir de las páginas siguientes consideramos necesario una aclaración terminológica de ambos conceptos. En la actualidad el Código de Derecho Canónico, C.298 afirma: Existen en la Iglesia asociaciones... en las que los fieles, clérigos o laicos, o clérigos junto con laicos, trabajando unidos, buscan fomentar una vida más perfecta, promover el culto público o la doctrina cristiana, o realizar otras actividades de apostolado, a saber, iniciativas para la evangelización, el ejercicio de obras de piedad o de caridad y la animación con espíritu cristiano del orden temporal. Definición que se completa en otros cánones, como se afirma en el c. 305: "Todas las asociaciones de fieles están bajo la vigilancia de la autoridad eclesiástica competente". Como se puede apreciar la jerarquía eclesiástica actual habla exclusivamente de asociaciones (no emplea ni el término cofradía ni el de hermandad) y las define de una manera muy amplia.

Pero el Código de Derecho Canónico anterior, promulgado en 1917, cc.700-725, daba una definición amplia y distinguía entre diferentes tipos de cofradías, y entre cofradías y hermandades. Así hablaba de: terceras órdenes, archicofradías, cofradías, pías uniones primarias, otras pías uniones. En el Canon 707 afirmaba: 1. Las asociaciones de fieles que han sido erigidas para ejercer alguna obra de piedad o de caridad, se denominan pías uniones; las cuales, si están constituidas a modo de cuerpo orgánico, se llaman hermandades. 2. Y las hermandades que han sido erigidas, además, para incremento del culto público reciben el nombre particular de cofradías.

De donde deducimos que la asociación constituida a modo de cuerpo orgánico que tiene por fin ejercer obras de caridad o de piedad es una hermandad; pero si esta hermandad se dedica al culto público recibe el nombre de cofradía. Por tanto, podemos concluir que existen hermandades sin ser cofradías, pero también cofradías que no son hermandades. Es decir, pueden existir hermandades que son cofradías, cofradías que son hermandades, hermandades solas sin ser cofradías, y cofradías que no son hermandades.

Lo dicho lo hemos encontrado afirmado de alguna manera por un documento fechado en Jerez, a 23 días de junio de 1392. En el mismo sencillamente se afirma: "e mando a la Cofradía de la Hermandad [... de Sant Saluador de la segunda hermandad (sic), onde él es cofrade, diez reales". ${ }^{9}$ De donde se deduce que una institución benéfica, cual era el Hospital de San Salvador de Jerez, era atendida por una hermandad y esta hermandad, suponemos que cuando realizaba actos de culto, se desdoblaba en una cofradía. Por tanto, podemos concluir que todas las cofradías jerezanas por nosotros estudiadas, en cuanto que atendían un hospital, eran hermandades. Por ello las denominamos indistintamente hermandades y cofradías.

Una cuestión de importancia singular que nos plantea la documentación es que la gran mayoría de las cofradías estudiadas tienen un hospital. De hecho en Sevilla, a excepción de la Hermandad de Criadores, todas se denominan como Hospital y Cofradía de.... ${ }^{10}$ Está claro que teniendo la

9 Rojas Vaca, M.D. 1998. Un registro notarial de Jerez de la Frontera (Lope Martínez, 1392): 193. Madrid: Fundación matritense del notariado.

$10 \quad$ Pérez González, S.M. 2005: 121. asociación un fin benéfico-asistencial se denomina cofradía y no hermandad (a excepción de un caso). Por tanto, se puede utilizar exclusivamente la palabra cofradía con los dos fines: benéfico-asistencial y piadoso-cultual.

En Jerez de la Frontera la situación es absolutamente heterogénea y se encuentra muy alejada de la homogeneidad que en su denominación presentan las cofradías de Sevilla por nosotros estudiadas en la monografía citada (puede que detrás de la misma se encuentre la influencia de la jerarquía eclesiástica, en un intento de dotar a estas instituciones de unos rasgos similares a fin de aplicarles con mayor eficacia la legislación vigente). Prueba de ello es el siguiente listado que recoge todas las cofradías jerezanas documentadas: ${ }^{11}$

Cofradía de la Hermandad de El Salvador. ${ }^{12}$ Esta denominación resulta de sumo interés pues da a entender que la institución principal es la hermandad, es decir, aquella parte que se dedica a las actividades benéfico-asistenciales y de ella depende la que se dedica a los cultos, la cofradía.

Cofradía de San Bartolomé. Tenía su advocación en la iglesia de El Salvador. ${ }^{13}$ No podemos determinar si fue antes cofradía o hermandad. Lo cierto es que en 1488 contaba con un hospital dedicado a recoger pobres enfermos para dormir. ${ }^{14}$

Cofradía de San Dionís. ${ }^{15}$ Podemos afirmar que también era una hermandad, pues en un testamento se pide que sus cofrades honren el cuerpo del difunto a cambio de 20 maravedís. ${ }^{16}$ En otra última voluntad se solicita que vengan a honrar al testador con las candelas de la Cofradía el día de su entierro, estando su cuerpo presente, por 30 maravedís. ${ }^{17}$

Cofradía de San Nicolás del Portal. ${ }^{18}$ En 1414 ya contaba con una regla y a ella se acoge un testador para que se le hagan las honras que le corresponden como cofrade, tal como figura en la normativa que rige el funcionamiento de la Cofradía. ${ }^{19}$

Cofradía de San Sebastián. ${ }^{20}$ En dos testamentos se solicita que el Hospital de San Sebastián ${ }^{21}$ forme parte de sendos cortejos fúnebres y en un tercero y cuarto que lo haga la Cofradía de San Sebastián. ¿Estamos ante dos instituciones diferentes, un

11 Las ordenamos alfabéticamente atendiendo a la denominación con la que aparecen en la documentación.

12 AMJFPN. Lope Martínez. 23 de junio de 1392. Fol.15v.

13 AMJFPN. Juan Martínez. 10 de febrero de 1414. Fol.173v.

14 Serrano Pinteño, J. 2010-2012 “El Hospital de la Sangre. De la fundación a la reducción de 1636. Nuevos datos". Revista de Historia de Jerez: 23.

15 Tenía su advocación en la iglesia de San Dionís. AMJFPN. Juan Martínez. 11 de enero de 1414. Fol.12r.

16 ĺdem.

17 AMJFPN. Juan Martínez. 31 de octubre de 1414. Fol.259r.

18 Situado a orillas del río Guadalete, era el puerto fluvial de la ciudad de Jerez de la Frontera.

19 AMJFPN. Juan Martínez. 6 de agosto de 1414. Fol.201r.

20 Posiblemente tenía su advocación en la iglesia de El Salvador. AMJFPN. Bartolomé de Maya. 7 de febrero de 1489. Fol.26v.; Juan Ortega Gaitán. 17 de abril de 1486. Fol.53r.; 5 de julio de 1490. Fol.119r.

21 Situado en el Llano de San Sebastián: Mariscal Trujillo, A. 2003. Por las calles del viejo Jerez: 107. Jerez de la Frontera: Ediciones Jerezanas. 
hospital y una cofradía, con la misma advocación? Pensamos que no, que se trata de una cofradía que rinde culto a san Sebastián y que regenta un hospital con el mismo nombre. ${ }^{22}$

Cofradía de Santa María. ${ }^{23}$ Tenía su advocación en la iglesia de El Salvador. No podemos determinar si también era una hermandad, puesto que la información que tenemos de esta institución se refiere al encargo de la celebración de una misa de réquiem cantada el día de santa María de agosto (15 de agosto, la Asunción) costeada con unas rentas.

Cofradía de Santa María de San Lucas. ${ }^{24}$ Deducimos que tenía su advocación en la iglesia de San Lucas, pero poco más podemos aportar sobre esta institución puesto que su nombre aparece en el deslinde de unas tierras como propietaria de un olivar.

Hermandad de Santa María de las candelas amarillas. ${ }^{25}$ Tenía su advocación en la iglesia de El Salvador y contaba con un hospital. Hemos de destacar que se trata de una hermandad formada exclusivamente por mujeres. De hecho figura en la última voluntad de tres testadoras, que realizan donaciones para el Hospital. No sabemos si también era una cofradía.

Cofradía de Santa María de Roncesvalles. ${ }^{26}$ Figura en un testamento cuyo titular pide que la Virgen interceda por su alma a cambio de una cantidad de dinero para la Cofradía.

Cofradía de señor San Cristóbal. ${ }^{27}$ También denominada Hermandad y Cofradía de San Cristóbal. ${ }^{28} \mathrm{Se}$ informa en la documentación que en 1490 tenía su advocación (sic) en el Hospital de Zurita también llamado de las Bubas. Estaba situado en la collación de San Dionisio, junto al monasterio de las monjas del Espíritu Santo. ${ }^{29}$ Este dato pone de manifiesto cómo los hospitales eran en muchos casos el centro de la actividad cultual de las cofradías, ${ }^{30}$ al tiempo que cumplían su función natural de ser centro de actividades asistenciales.

Cofradía de señor San Francisco. ${ }^{31}$ No sabemos si se refiere a la Cofradía de San Luis que tenía su advocación en el Convento franciscano o a una cofradía bajo la advocación del santo de Asís.

Cofradía del Hospital de San Blas. ${ }^{32}$ Estaba situado en la calle que va del Mercado a la Puerta de Rota en

22 Quizás se trate del mismo hospital que aparece en AHMJF. Beneficencia y Sanidad. Leg.7. Autos originales de la Reducción de Hospitales al fundado por el Beato Juan Pecador (1589-1593) bajo la denominación de Hospital de San Sebastián y San Juan de Letrán, que estaba situado frente al Convento de Santo Domingo en la collación de Santiago, y era administrado por cofrades.

${ }^{23}$ Advocación en la iglesia de El Salvador AMFJPN. Gonzalo Román. 16 de agosto de 1471. Fol.522r.; Bartolomé de Maya. 7 de febrero de 1489. Fol.26v.

24 AMJFPN. Juan Martínez. 21 de agosto de 1414. Fol.213r.

25 AMJFPN. Juan Martínez. 20 de marzo de 1414. Fol.112v.; 28 de marzo de 1414. Fol.134v.

26 AMJFPN. Juan Martínez. 10 de febrero de 1414. Fol.173v.

27 AMJFPN. Bartolomé de Maya. 31 de julio de 1490. Fol.114r.

28 AMJFPN. Juan Ortega Gaitán. 5 de mayo de 1490. Fol.67r.

29 Serrano Pinteño, J. 2010-2012: 38.

30 Pérez González, S.M. 2005: 181.

31 AMJFPN. Juan Martínez. 13 de febrero de 1414. Fol.86r.

32 AMJFPN. Bartolomé de Maya. 5 de mayo de 1489. Fol.81v. la collación de San Mateo. Este caso es similar al de la Cofradía de la Hermandad de San Salvador, con la diferencia de que no se hace uso del término hermandad aun cuando existía una dedicada a san Blas, puesto que se hace referencia a un hospital. Serrano Pinteño confirma la existencia de la hermandad..$^{33}$

Hermandad del Hospital de Santa María del Pilar. ${ }^{34}$ Tenía su sede canónica en el Convento de San Francisco. Pese a que sólo aparece con la denominación de Hermandad, sabemos que también era una cofradía pues se cita como cofrades de la misma a Juan García (roto), Álvarez de Solís, Francisco Martínez Hamusgo, Benito Sánchez de Madrid, Diego Martínez de Cota, Antón (roto)..$^{35}$ El Hospital estaba situado a la entrada de la calle Guarnidos, en la collación de San Miguel. ${ }^{36}$

Hermandad y Cofradía de la Misericordia. ${ }^{37}$ En ocasiones sólo se la menciona con el nombre de la dependencia donde desarrolla parte de su actividad asistencial, esto es, el Hospital de la Misericordia, situado a las espaldas de la iglesia de San Dionisio, junto a la plaza de las frutas. ${ }^{38}$ En un testamento se hace referencia a la Cofradía de la Hermandad de la Misericordia, como encargada de celebrar unas honras fúnebres. ${ }^{39} \mathrm{~A}$ sus miembros se les denomina "hermanos y cofrades". ${ }^{40}$ Serrano Pinteño confirma la existencia de una cofradía. ${ }^{41}$ El Hospital fue suprimido en 1589 con la reducción llevada a cabo por el cardenal don Rodrigo de Castro (Arzobispo de Sevilla entre 1581 y 1600). En el siglo xv se conocía a la calle en la que estaba situado como la calle de los hermanos de la Misericordia. ${ }^{42}$

Hermandad y Cofradía de San Luis..$^{43}$ En este caso no hay lugar para la duda.

Hospital de Santa María. ${ }^{44}$ En el Protocolo notarial se dice literalmente de la iglesia de San Juan y en esta parroquia tenía su sede canónica. Serrano Pinteño nos indica que también se denominaba de la Natividad y estaba situado en la plaza de San Juan. ${ }^{45}$ Según Sancho de Sopranis su denominación era Hospital era Santa María de Hinojosa, pues fue fundado en 1362 por Gil de Hinojosa, Martín de Hinojosa y María Sánchez, esposa de este último. ${ }^{46}$ La institución hospitalaria acogía a peregrinos pobres y daba una limosna a las ancianas recogidas. La exis-

33 Serrano Pinteño, J. 2010-2012: 24.

34 AMJFPN. Juan Ortega Gaitán. 11 de junio de 1490. Fol.99v.; Juan Román. 25 de noviembre de 1501. Fol.394v.

35 AMJFPN. Juan Román. 25 de noviembre de 1501. Fol.394v.

36 Serrano Pinteño, J. 2010-2012: 23.

37 AMJFPN. Bartolomé de Maya. 4 de abril de 1489. Fol.55v.

38 AMJFPN. Juan Ortega Gaitán. 30 de junio de 1490. Fol.113v.

39 AMJFPN. Juan Ortega Gaitán1 de octubre de 1490. Fol.147v.

40 AMJFPN. Bartolomé de Maya. 4 de abril de 1489. Fol.55v.

41 Serrano Pinteño, J. 2010-2012: 24-25.

42 AMJFPN. Juan Ortega Gaitán. 24 de septiembre de 1490. Fol.141v.

43 Tenía su advocación en el Convento de San Francisco AMJFPN. Gonzalo Román. 10 de noviembre de 1470. Fol.69v.

44 AMJFPN. Bartolomé de Maya. 5 de mayo de 1489. Fol.81v.

45 Serrano Pinteño, J. 2010-2012: 24.

46 Sancho De Sopranis, H. 1973. Mariología medieval xeriecense: 56. Jerez de la Frontera: Centro de Estudios Históricos Jerezanos. 
tencia de su cofradía se confirma por el encargo de la celebración de unas remembranzas.

Hospital de la iglesia de San Marcos, al que se donó un almadraque usado. ${ }^{47}$ García Guzmán y Abellán Pérez afirman que estaba a cargo de la Cofradía de la Concepción y San Marcos. Acogía a doce mujeres pobres y ancianas, proporcionándoles casa y carbón. ${ }^{48}$

Hospital de la Sangre de Jesucristo. ${ }^{49}$ Debía contar con una cofradía que recibió varios encargos de formar parte de cortejos fúnebres así como de enterramientos en la instalación hospitalaria, que estudiamos más adelante.

Además de las hermandades y cofradías relacionadas Sancho de Sopranis recoge las siguientes: ${ }^{50}$ Cofradía de Santa María de la Merced y Cofradía de Santa María del Alcázar. ${ }^{51}$

Esta vinculación entre hospital y cofradía nos lleva a preguntarnos en relación con el origen de cada uno de ellos: ¿qué surgió antes, la cofradía o el hospital? En el caso de Sevilla, al carecer de documentos fundacionales, no pudimos dar una respuesta absoluta a este interrogante y nos planteamos una doble posibilidad. Pudo ocurrir que existiendo previamente una cofradía ésta decidiese fundar un hospital para canalizar sus actividades internas (actos de culto) y las de índole benéfico-asistencial. Por tanto, la cofradía precedió al hospital en cuanto a una existencia previa. Pero también pudo darse el caso de que, habiéndose fundado primero un hospital, luego nació en él una cofradía para atenderlo. La iniciativa de este nacimiento pudo partir de un particular o de un número determinado de personas ligadas a un oficio o a un grupo social determinado.

Sin embargo el caso de Jerez de la Frontera es absolutamente ilustrativo, pues contamos con documentación relativa a la fundación de hospitales y de sus cofradías y hermandades. Antes de entrar a detallar algunos de ellos queremos destacar la importancia de Jerez en este sentido pues el hecho de que, a nuestro entender, se encuentre en un momento evolutivo anterior al de las hermandades y cofradías de Sevilla nos permite arrojar luz a un tema tan complejo, por el silencio documental, como es el origen de estas instituciones. Pasamos, pues, a analizar los casos más relevantes por contar con datos documentales al respecto.

El Hospital de la Sangre fue fundado por iniciativa particular con anterioridad a $1477 . .^{22}$ En octubre de ese año los Reyes

\footnotetext{
47 AMJFPN. Juan Martínez. 27 de marzo de 1448. Fol.128r.

48 García Guzmán, M.M. y Abellán Pérez, J. La religiosidad de los jerezanos según sus testamentos (siglo XV): 29. Cádiz: Agrija Ediciones.

${ }^{49}$ AMJFPN. Juan Ortega Gaitán. 7 de junio de 1490. Fol.95r.; 5 de julio de 1490. Fol.122v.; 8 de julio de 1490. Fol.124r.

50 Sancho De Sopranis, H. 1973: 54, 56. Centro de Estudios Históricos Jerezanos.

51 Además de estas hermandades y cofradías documentamos un hospital, el de San Miguel, de los que no podemos afirmar si era atendido por alguna de estas instituciones. Estaba situado en la collación de San Miguel y recibió la donación de un almadraque lleno de lana para los pobres (AMJFPN. Juan Martínez. 3 de septiembre de 1448. Fol.110v.) y otro almadraque usado (AMJFPN. Juan Martínez. 21 de marzo de 1448. Fol.114v.). Quizás el estudio de la documentación posterior al periodo analizado nos permita aportar más datos sobre esta institución.

52 Serrano Pinteño, J. 2010-2012: 1.
}

Católicos visitaron Jerez y Nuño García, carpintero, les solicitó, en calidad de fundador, patrón y administrador, inmunidad fiscal y permiso para recibir limosnas y tributos para el hospital que había fundado en unas casas de su propiedad frente a la iglesia de Santiago. Estaba dedicado a acoger y hospedar a pobres, dándoles cama y ropa, y curarlos de sus enfermedades. El ocho de octubre de 1477 la Corona concedió la franqueza. ${ }^{53}$ En 1482 no se había conseguido plenamente dicha franqueza, pues el hospital a través de sus hermanos mayores hubo de reclamar sus derechos ante el cabildo municipal, lo que sólo le fue concedido parcialmente a Juan Rodríguez, capellán del Hospital de la Sangre de Jesucristo. ${ }^{54}$

Según Serrano Pinteño la confirmación de la Cofradía del Hospital de la Sangre fue otorgada por don Pedro Fernández de Solís, Obispo de Cádiz y Provisor del Arzobispado de Sevilla, lo que debió producirse entre 1474 y 1483 . Este autor utiliza indistintamente los términos hermandad y cofradía, por lo que podemos pensar que se trata de una institución que ejercía las dos vertientes antes definidas, caritativa y cultual. Como cofradía aparece definida en el testamento del fundador, otorgado el siete de junio de 1485, del que no se conserva el original sino una copia protocolizada del siglo XVII de un traslado solicitado anteriormente.

En la última voluntad de Nuño García se dice expresamente que lo entierren en el hospital que él fundó y edificó, lo cual no deja duda a la iniciativa particular como origen de la institución que pronto contaría con una cofradía para atenderlo. Fijó el lugar de su sepultura, junto al altar mayor que estaba dedicado a santa María, al tiempo que legó la administración y patronazgo del Hospital, al que nombró su heredero universal, a los cuatro hermanos mayores que en ese momento tenía la Cofradía de la Sangre. ${ }^{55}$ Durante el siglo XVI la institución recibió pingües legados y donaciones por parte tanto de miembros de ilustres familias caso de doña Beatriz Pacheco, duquesa de Arcos, los Hinojosa, o los Sotomayor, como de los integrantes de los grupos intermedios de la sociedad jerezana finimedieval. Gracias a ello el Hospital adquirió un importante patrimonio en dinero, tierras, inmuebles, censos y, lo que resulta de enorme interés, una dotación de enfermeros que incluía unas ordenanzas para el funcionamiento de este cuerpo así como un tributo perpetuo para criar a niños expósitos. ${ }^{56}$ Finalmente recibió varias fundaciones de capellanías ricamente dotadas. De ellas se encargaban los capellanes, ocupando este cargo en 1490 Juan Rodríguez, capellán del Hospital. ${ }^{57}$

53 Archivo General de Simancas: Mercedes y privilegios. Hospital de Nuño García. Franqueza de tributos para una persona que demandase limosna para el dicho hospital. 8 de octubre de 1477.

54 AMJFPN. Juan Ortega Gaitán. 5 de noviembre de 1490. Fol.218r.

55 En un principio Nuño García pidió al papa Sixto IV, el gran impulsor de la devoción a la Sangre de Jesucristo, que a su muerte el patronato pasara al Monasterio cartujano de Santa María de la Defensión. Le fue otorgado pero luego el fundador decidió otorgárselo a la Cofradía de la Sangre radicada en el Hospital por razones legales que no especifica.

56 García Herrero, M.C. 1990. Las mujeres en Zaragoza en el siglo xv: 115-117. Zaragoza: Ayuntamiento de Zaragoza. Pérez González, S.M. 2012 "De la tipificación a la realidad documentada: Las jerezanas a fines de la Edad Media (1392-1505)". Religiosidad Sevilla: Homenaje al profesor Sánchez Herrero: 443-444. Sevilla: Aconcagua Libros.

57 AMJFPN. Juan Ortega Gaitán. 5 de noviembre de 1490. Fol.218r. 
Pese a llevar varios años funcionando la Cofradía, la confirmación definitiva no llegó hasta 1489, con motivo de la visita pastoral de don Francisco Reinado Romero, obispo de Tiberiades. Al mismo tiempo el arzobispo de Sevilla don Diego Hurtado de Mendoza ingresó como hermano de la Cofradía de la Sangre, entregando como cuota de ingreso unas casas bodega en la collación de San Marcos. ${ }^{58}$

Queremos destacar, aunque no es objeto de estudio del presente trabajo, la importancia que el culto a la Sangre de Jesucristo adquirirá a partir del pontificado de Sixto IV (1471-1484) y con él el nacimiento de las cofradías de Semana Santa. ${ }^{59}$ De hecho el Hospital fundado por Nuño García nació bajo la advocación de santa María de Dios, pero luego pasó a estarlo bajo la de la Sangre.

Otro ejemplo ilustrativo sería el del Hospital de San Cristóbal, también Ilamado de Zurita. Su origen se encuentra en el testamento de Mencía Suárez de Moscoso, viuda del maestresala y embajador de Juan II en Granada don Diego Fernández de Zurita y Colsantos, ${ }^{60}$ redactado el 25 de mayo de 1466 ante Gonzalo Román. El fin del mismo era cuidar y atender a doce pobres, preferentemente de origen aristocrático, para lo que la fundadora lo dotó con varios bienes en la collación de San Dionisio. La asistencia espiritual fue encomendada a los franciscanos y el patronato lo ejercería el pariente mayor de la casa de Zurita. Según Muñoz y Gómez ya existía en la iglesia de El Salvador la Hermandad de San Cristóbal desde 1317, pasando dicha Cofradía en 1490 a atender la curación y atención de los enfermos en el Hospital, tomando el mismo el nombre de San Cristóbal. ${ }^{61}$ Más tarde el Hospital se especializó en la curación de bubas. Tras numerosos pleitos el legado de Mencía Suárez de Moscoso fue absorbido por el Monasterio del Santo Espíritu, que fue fundado en 1543 por los Zuritas para enterrar a los miembros de la familia. ${ }^{62}$ El Hospital superó el proceso de reducción de mediados del siglo XVI por su especialidad médica y por su capacidad para atender a más de un centenar de enfermos.

Por último tenemos el caso del Hospital de Santa María, que fue fundado por Gil de Hinojosa, Martín de Hinojosa y María Sánchez, su mujer, en 1362. Estaba destinado a

58 Serrano Pinteño, J, 2004. “Reformas barrocas en el Hospital de la Sangre de Jerez de la Frontera: Juan Díaz de la Guerra y Rodrigo de Alva". Revista de Historia de Jerez 10: 2004.

59 Repetto Betes, J.L. (Coord). 1995. La Semana Santa de Jerez y sus cofradías: 13-19. Jerez de la Frontera: Ayuntamiento de Jerez; Riera Vayreda, F. 1997. "La Cofradía de la Sangre del Hospital General de Mallorca". Memoria Ecclesiae 11: 505-511; Sánchez Herrero, J. y Pérez González, S.M. 1999. "La devoción a la Preciosa Sangre de Cristo de Sevilla: La importancia de la devoción a la preciosa sangre de Cristo en el desarrollo de la devoción y la imaginería de la Semana Santa? Aragón en la Edad Media 14-15: 1429-1452; Arboleda Goldaracena, J.C. 2012. "La devoción a la Sangre de Cristo y el origen de las cofradías penitenciales a fines de la Edad Media: el caso de la ciudad de Málaga. Revista de Historia Autónoma 1: 73-88.

60 Sancho De Sopranis, H. 1929. “Diego Fernández de Zurita, alcalde de Arcos, embajador en Granada" Revista de Historia y de Genealogía Española, 2o época, III: 11-42, 107-116, 326-337. Ruiz Pilares, E. (en prensa). "El linaje de los Zurita: un caso arquetípico en la formación y consolidación de la élite jerezana en la Baja Edad Media".

61 Serrano Pinteño, J. 2010-2012: 24.

62 Sancho De Sopranis, H. 1964-1969. Historia de Jerez de la Frontera desde su incorporación a los dominios cristianos: 90. Jerez: Jerez Industrial. recoger peregrinos mendigos a los que se les daba cama para dormir. ${ }^{63}$

Por lo que se refiere a la tipología podemos distinguir tres grupos:

Cofradías Cristológicas: Hospital y Cofradía de la Sangre de Jesucristo y la Cofradía de la Hermandad de El Salvador.

Cofradías Marianas: Hermandad del Hospital de Santa María del Pilar, Cofradía de Santa María (de El Salvador), Cofradía de Santa María de Roncesvalles, Hermandad de Santa María de las candelas amarillas, Cofradía de Santa María (iglesia de San Lucas), Cofradía de Santa María de la Merced y Cofradía de Santa María del Alcázar.

Cofradías alusivas a los Santos: Hermandad y Cofradía de San Luis, Cofradía de San Sebastián, Cofradía del Hospital de San Blas, Cofradía de señor San Cristóbal, Cofradía de señor San Francisco, Cofradía de San Nicolás del Portal. Dentro de este grupo se encuentran las cofradías parroquiales, cuya advocación coincidía con la del santo titular de la parroquia, por lo que suponemos serían muy difundidas por el clero parroquial en orden a solemnizar sus cultos: Cofradía de San Dionís.

Como puede observarse, predominan las cofradías dedicadas a los santos, con un número de ocho representantes, a la Virgen con siete instituciones y dos a Jesucristo. En estos porcentajes el caso de Jerez de la Frontera es similar al de Sevilla.

\section{EL GOBIERNO DE LAS COFRADÍAS}

La documentación estudiada nos informa de las siguientes juntas de gobierno:

Cofradía de Santa María del Pilar: ${ }^{64}$ Hermanos mayores: Diego Rodríguez, espartero, y Pero Martínez Manzano. Mayordomo: Antón Martínez de la Bona. Diputados: Antón Jiménez de Tarifa y Juan Rodríguez de Alburquerque.

Cofradía de San Luis: ${ }^{65}$ Alcalde: Bartolomé Ruiz, tejedor. ${ }^{66}$ Prioste: Bartolomé Ruiz, tejedor. ${ }^{67}$

Cofradía de Santa María:68 Priosta: Elvira Alfonso, viuda de Alfonso Vergado.

Cofradía de San Cristóbal: ${ }^{69}$ Hermano mayor: Francisco López, espadero. Gonzalo Sánchez y Andrés García. ${ }^{70}$ Alcalde: Antón Gómez, borceguinero. Diputados: Juan Rodríguez, librero, Alfonso Gutiérrez, sastre, y Francisco López, espadero Procurador: Andrés Franco.

63 Sancho De Sopranis, H. 1973. Mariología medieval xericense: 56. Jerez: Centro de Estudios Históricos Jerezanos. Muñoz Y Gómez, A. 2010. Noticia histórica de las calles y plazas de Xerez de la Frontera: 87-88. Valladolid: Maxtor.

64 AMJFPN. Juan Román. 25 de noviembre de 1501. Fol.394v.

65 AMJFPN. Gonzalo Román. 10 de noviembre de 1470. Fol.69v.

66 AMJFPN. Gonzalo Román. 11 de noviembre de 1470. Fol.70v.

67 AMJFPN. Juan Martínez. 8 de abril de 1448. Fol.43v.

68 AMFJPN. Gonzalo Román. 16 de agosto de 1471. Fol.522r.

69 AMJFPN. Bartolomé de Maya. 31 de julio de 1490. Fol.114r.

70 AMJFPN. Juan Ortega Gaitán. Jueves 5 de mayo de 1490. 
Cofradía de San Sebastián: ${ }^{71}$ Alcalde: Antón García Palomino, sillero. Prioste: Bartolomé García del Puerto. Diputado: Martín de Aguilar.

La primera conclusión que podemos extraer del estudio de los cargos mencionados es que las cofradías jerezanas bajomedievales, utilizando un concepto actual, se regían por unas juntas de gobierno muy simples en lo que a sus componentes se refiere. ${ }^{72}$ La proliferación actual de cargos, algunos de ellos con una gradación entre quienes se acogen bajo una misma denominación (mayordomo primero y segundo o secretario primero, segundo, y hasta tercero) contrasta de forma evidente con estas cofradías que estudiamos, muy sencillas en la composición de las juntas rectoras.

La junta de gobierno más completa sería la que componían, por orden alfabético y no de importancia de sus competencias, un alcalde, un diputado, un hermano mayor, un mayordomo, y un prioste. Las cofradías que contaban con este órgano gubernativo al completo habrían alcanzado un elevado grado de madurez en el desarrollo de sus funciones internas. En el resto de los casos, especialmente en el de aquellas cofradías cuyas juntas se componen de tan sólo tres miembros, cabe barajar una doble posibilidad: que se hallaban en una fase de evolución menos desarrollada por haber tenido una fundación reciente o porque no necesitaba más oficiales que los citados para el despliegue de sus distintas actividades; o bien que, teniendo en cuenta que estas juntas de gobierno las hemos reconstruido extrayendo los datos a partir los Protocolos notariales, en las cofradías indicadas esa documentación no se ha conservado o no ha habido actuación de alguno de sus cargos y, por tanto, no hay constancia documental del mismo. En cualquier caso llama la atención, frente a la casi omnipresencia documentada en Sevilla, que en ninguno de los ejemplos analizados se mencione al escribano de la cofradía. ${ }^{73}$

Con respecto a las funciones que desempeñaban cada uno de estos miembros de las juntas de gobierno, hemos de decir que la documentación no es muy ilustrativa al respecto. No podemos deducir las funciones por ellos desarrolladas a partir de los Protocolos estudiados. La información que éstos nos proporcionan se limita a indicar su nombre y su participación en el negocio queda reducida a la de simples suscriptores del mismo, sin que realicen ninguna otra actividad derivada del oficio que cumplían.

A diferencia de lo que sucedía en Sevilla, en cuyas cofradías el prioste tenía un protagonismo decisivo en la vida de la cofradía, al menos en lo que se refiere al despliegue de las actividades que la implican directamente en la sociedad, en el caso de Jerez de la Frontera su importancia es sustancialmente menor. Consideramos que son los hermanos mayores quienes ocupan el lugar más importante en el gobierno de las cofradías. De hecho, durante el proceso de reducción hospitalaria llevado a cabo en el siglo XVI, quienes representan a las hermandades ante las autoridades eclesiásticas, presentando

71 AMJFPN. Juan Ortega Gaitán. 17 de abril de 1486. Fol.53r.

72 Arboleda Goldaracena, J. C. 2012. "El gobierno de las hermandades y cofradías andaluzas en la Baja Edad Media", en Arízaga Bolumburu, B. et alii (eds.), Mundos medievales: espacios, sociedades y poder. Homenaje al Prof. José Ángel García de Cortázar, t. II: 10051014. Santander: Universidad de Cantabria.

73 Pérez González, S. M. 2005. 135-137. alegaciones y trasladando la documentación exigida, son los hermanos mayores. ${ }^{74}$

Ello no es óbice para que los priostes sean protagonistas de algunos negocios importantes para las cofradías. Ejemplo de ello son Bartolomé Ruiz, tejedor, prioste de la Cofradía de San Luis, quien en nombre de la Cofradía compró unas casas. ${ }^{75} \mathrm{Y}$ sobre todo el caso de Elvira Alfonso, viuda, priosta de la Cofradía de Santa María. ${ }^{76}$ Afirmábamos allá por el año 2001 en nuestra Tesis doctoral: “¿Hubo mujeres en las cofradías? Sí, pero de su condición de cofradas siempre se nos informa de manera indirecta: no acuden a los cabildos ni pertenecen a las juntas de gobierno, por lo que no aparecen en los listados de cofrades" ${ }^{77}$ Afortunadamente para el avance de la ciencia histórica tenemos que corregirnos a nosotros mismos y en el caso de la ciudad de Jerez de la Frontera sí hemos documentado una cofradía, la de Santa María que tenía su advocación en la iglesia de El Salvador, cuyo prioste o, mejor dicho, cuya priosta era una mujer. En el caso de Elvira ella, de acuerdo con una función específica de su cargo, recibió el pago de las rentas de unas casas pertenecientes a la Hermandad por parte de Pedro de Fuentes, escribano de la justicia. Queremos destacar la importancia de este documento pues, según los datos de que disponemos, estamos ante una de las pocas cofradías en cuya junta de gobierno figura una mujer. Pero no podemos determinar si Elvira ejercía su priostía en una hermandad de mujeres ${ }^{78}$ o mixta, ya que no podemos afirmar si se trata de la Cofradía de Santa María de las candelas amarillas, que también tenía su advocación en El Salvador, porque la documentación sólo recoge la advocación mariana y la sede canónica.

El número de personas que pueden ocupar un mismo cargo nos es desconocido y como puede observarse en las juntas recogidas no hay regularidad alguna. Normalmente en el caso de los hermanos mayores son dos, uno es el número de priostes, alcaldes y mayordomos, mientras que el de los diputados es variable. En relación con el cargo de diputado, la variación en el número de personas que lo desempeñaron puede explicarse por la siguiente razón: da la impresión de que en la época estudiada este cargo no estaba consolidado como tal, sino que se trataba de personas designadas por la cofradía para cumplir una misión concreta.

\footnotetext{
74 Serrano Pinteño, J. 2010-2012: 26.
}

75 AMJFPN. Juan Martínez. 8 de abril de 1448. Fol.43v.

76 AMJFPN. Gonzalo Román. 16 de agosto de 1471. Fol.522r.

77 Parece ser que tampoco hubo mujeres desempeñando cargos públicos en la Inglaterra medieval: "Within the towns public authority was confined to men. Women did not become members of the ruling council or its head. Nor did they hold any of the lesser civic offices. Even though women could join some guilds and craft fellowships as members, paid annual dues and as widows continued to run their husbands' businesses, they were not eligible for guild office" (MATE, M.E. 1999. Women in Medieval English society: 63 Cambrige, University Press). "Within the city of London, with its large number of fraternities, there is no evidence of women holding office" (ROSSER G. 1990. "The Essence of Medieval Urban Communities: the Vill of Westminster, 1200-1540". The Medieval Town: 216-237. London. BARRON, C. 1985. "The Parish Fraternities of Medieval London". The Church in PreReformation Society: 13-37. Woodbridge: The Boydell Press).

78 Sobre cofradías de mujeres véase: Casquero Fernández, J. A. 1997. "La religiosidad de las mujeres: las cofradías de Santa Águeda en la diócesis de Zamora, siglos XVII-XIX". Religiosidad popular en España: 57-80. V. I. Madrid: Estudios Superiores de El Escorial. 
Un aspecto que desconocemos es la cuestión de las elecciones, en concreto el tiempo que transcurría entre los nombramientos para cada uno de los cargos. Lo mismo sucede en relación con los cabildos, pues no hemos documentado ninguna de estas reuniones fundamentales para el gobierno de las cofradías.

Las juntas recogidas en la documentación nos permiten conocer algunos datos en relación con los cofrades. No son muchos puesto que, como hemos dicho los Protocolos notariales nos ofrecen la faceta mundana de la cofradía, sus implicaciones con la sociedad jerezana. Las cuestiones relativas a su funcionamiento interno quedan fuera del ámbito de las escribanías públicas. Para dichas actividades propias las cofradías tuvieron su archivo en el que custodiaban sus libros, libros de cuentas, libros de donaciones, y por supuesto, los llamados libros de abc, donde quedaban recogidos en listados ordenados alfabéticamente los nombres de sus cofrades. El hecho de no haberse conservado estos libros nos impide conocer una serie de cuestiones como el número de cofrades con el que cada cofradía contó en distintas épocas, el ritual de ingreso y el proceso previo a la autorización para llevarlo a cabo, el pago de cuotas, la posibilidad de que existieran determinados condicionantes (étnicos, profesionales, sociales, etc.) que impidiesen el acceso, el grado de participación en la vida de la cofradía, etc.

Pero podemos conocer algunas profesiones que organizamos por sectores: artesanía del libro: librero; cuero: borceguinero y sillero; metal: espadero; y textil: sastre y tejedor. Estos escuetos datos no nos permiten hablar de cofradías profesionales que, para la época estudiada, eran muy escasas en Sevilla predominando aquéllas en las que el elenco de profesionales era extraordinariamente variado en cuanto a la dedicación laboral. ${ }^{79}$ Sí podemos afirmar a partir de la información recogida que las cofradías eran instituciones generadas e integradas por los sectores intermedios de la sociedad $y$, especialmente, por miembros del sector secundario dedicados a las actividades artesanales.

\section{LAS BASES ECONÓMICAS DE LAS COFRADÍAS}

Dentro del conjunto de bienes que conforman el patrimonio de las cofradías podemos distinguir tres grandes grupos: casas, propiedades rurales y los que integran el capital artesanal de las mismas. ${ }^{80}$

Dentro del patrimonio de las cofradías destacan de forma absolutamente predominante los bienes inmuebles: casas, corrales y solares. Todo parece indicar que fueron la compensación que prefirieron para sufragar los cultos que se les encargaba. Ciertamente, cabe la posibilidad de pensar que las casas generaban unas rentas fijas que asegurarían, al menos teóricamente, el cumplimiento ad perpetuum de las disposiciones de quienes las donaban. Pero también lo hacían las propiedades rurales y la donación de éstas es muy inferior. No debemos olvidar que la mayoría de los cofrades se dedicaban a actividades vinculadas con los oficios urbanos, por lo que la gestión de los bienes de la cofradía se vería facilitada por el hecho de estar situados en la propia

\footnotetext{
79 Pérez González, S.M. 2005: 128-131.

80 A diferencia de Sevilla no hemos documentado ninguna cofradía propietaria de ganados. Pérez González, S.M. 2005: 163-164.
}

ciudad. Se ocuparían de supervisarlos al finalizar la jornada laboral, sin tener que desplazarse fuera del recinto urbano.

En cuanto a la tipología de las casas hemos de decir que la documentación no es muy ilustrativa al respecto. Bajo una denominación siempre en plural se encierra un conjunto formado, en la gran mayoría de los casos, por unos palacios, soberados, y corral. Nada se indica de cuestiones como el tamaño. Tampoco son muy ilustrativos los documentos que tienen como objeto de un determinado negocio los corrales. No creemos que sea posible dilucidar esta cuestión a partir de las rentas fijadas en los contratos de arrendamiento. En las cantidades que habrían de pagar los inquilinos debieron influir otros factores, además de las proporciones de las casas: la situación en la ciudad y dentro de la collación, el estado de conservación, el disponer de alguna infraestructura especial como pozos, ${ }^{81}$ los materiales constructivos, etc.

La documentación estudiada apenas nos informa sobre cómo esas propiedades inmobiliarias fueron adquiridas por las cofradías. Sólo se hace referencia a dos vías: la compra directa, de forma muy minoritaria, y, sobre todo, las donaciones. En estas últimas intervienen dos motivaciones muy relacionadas que las justifican: por un lado, la devoción que se tiene a una determinada cofradía; y por otro, garantizar con las rentas que generen las casas donadas el cumplimiento de una serie de cultos y honras fúnebres.

Como ejemplo de compra tenemos el caso de la Cofradía de San Luis, con advocación en el Convento de San Francisco, cuyo prioste acompañado por un cofrade se encargó de comprar a Domingo Rodríguez, monedero, unas casas con corral, trascorral y un pozo de agua, por 7.200 maravedís pagados que fueron pagados al contado. ${ }^{82}$ La propiedad adquirida tenía un cargo de 15 maravedís anuales pagaderos perpetuamente para una remembranza de vigilia y misa que los clérigos de la iglesia de San Miguel celebraban cada año. Desconocemos si tras la compra se efectuaría el ritual propio del acto jurídico que representaba la toma de posesión, heredado del Derecho Romano: abrir las puertas, penetrar en las casas y recorrer todos sus rincones.

Entre los negocios de que son objeto las casas destacan de forma mayoritaria los arrendamientos. Existe una predilección en las cofradías por someter sus propiedades inmobiliarias a alquileres por una o varias vidas, lo que puede obedecer a varios motivos. En primer lugar en la época que estudiamos no había un control tan exhaustivo de la economía cofrade, entre otras razones porque en las juntas de gobierno no había una persona dedicada exclusivamente a ella, como los actuales tesoreros. Todos, oficiales y cofrades, aparecen implicados en negocios de variada naturaleza, en el tiempo que sus ocupaciones personales y profesionales les dejaba. Con estos contratos de larga duración las cofradías trataban de asegurarse unas rentas fijas durante un periodo de tiempo prolongado, sin necesidad de revisar periódicamente los contratos o confeccionar otros nuevos. Lógicamente ello conllevaba el que los alquileres permaneciesen fijos durante un número importante de años, pese al lógico incremento del coste de la vida. Pero insistimos: no es el afán de lucro lo que distingue a las cofradías. Tan

\footnotetext{
81 AMJFPN. Juan Ortega Gaitán. 5 de mayo de 1490. Fol.67r.

82 AMJFPN. Juan Martínez. 8 de abril de 1448. Fol.43v.
} 
sólo persiguen el cobro regular de unas rentas con las que costear sus actividades.

Como ejemplo de ello podemos mencionar el corral que la Cofradía de Santa María de la iglesia de El Salvador tenía arrendado por su vida y una renta de 50 maravedís al escribano Pedro de Fuentes. Fue su priosta, Elvira Alfonso, la encargada de cobrar todo lo que Pedro debía de ciertos años pasados y hasta el día de Santa María de agosto de $1471 .^{83}$

Otro contrato que ilustra lo afirmado es el que intitula la Hermandad y Cofradía de San Cristóbal. Sus hermanos mayores y un diputado arrendaron por su vida a Francisco Martínez, armador, una solar en la $\mathrm{Cruz}^{84}$ que lindaba con otros dos solares que tenía arrendados de la Hermandad Pero Alfonso, espartero, por 400 maravedís anuales. ${ }^{85}$ Los plazos de pago fueron dos: la mitad el día de san Cristóbal y la otra mitad el día de Pascua. ${ }^{86}$

En cuanto a las rentas percibidas podemos observar que éstas sólo se pagan en dinero, expresadas en maravedís y doblas, y que ninguna de ellas conlleva el pago en especie. ${ }^{87}$ No nos parece significativo indicar una cantidad media, pues en los alquileres, como hemos indicado, inciden muchos factores propios y específicos de cada propiedad. Tampoco podemos establecer una periodicidad en el pago de esos alquileres, pues la escasa documentación no nos lo permite. Sí podemos observar alguna preferencia por percibir las rentas en fechas acordes con los cultos y celebraciones propias de las cofradías. Es el caso del pago de la mitad de la renta el día de san Cristóbal por la Hermandad de esta advocación, o el día de Santa María de agosto.

Lógicamente el impago de alquileres debió darse con más frecuencia de la que recoge la documentación estudiada. Sólo contamos con el ejemplo del jurado Pedro de Fuentes y su incumplimiento del pago del contrato de arrendamiento a la Cofradía de Santa María cuya priosta se encargó de solventar.

En todos los casos estudiados los arrendamientos se produjeron de forma directa entre la cofradía y el inquilino, sin que documentemos permisos por parte de las autoridades eclesiásticas ni remates, esto es, pujas por el inmueble tras su anuncio público por medio del pregonero municipal. ${ }^{88}$

En ocasiones las propiedades inmobiliarias obligaron a las cofradías a intervenir en pleitos por su propiedad con particulares. Así le ocurrió a la Cofradía de San Blas de la iglesia de San Mateo, a la que Diego Ferrández, jurado, vecino de la collación de San Marcos, debía sesenta doblas de oro tras el acuerdo a que llegó con los cofrades, según declara en su testamento. El objeto del pleito fueron unas casas que pertenecieron a María Martín la sota, localizadas en la collación de San Lucas. Ambos, Cofradía y jurado, pleitearon por las casas pues ambos se consideraban herederos

\footnotetext{
83 AMFJPN. Gonzalo Román. 16 de agosto de 1471. Fol.522r.
}

${ }_{84}$ Quizás se trate de la Cruz Vieja: Cirera González, J.A. 2004. Calles jerezanas que fueron conocidas por otros nombres en el siglo XX: 34. Jerez de la Frontera: Ediciones AE; Mariscal Trujillo, A. 2003. Por las calles del viejo Jerez. Jerez de la Frontera: 70-72. Jerez de la Frontera. Ediciones Jerezanas.

85 AMJFPN. Juan Ortega Gaitán. 16 de junio 1490. Fol.101v.

${ }^{86}$ AMJFPN. Juan Ortega Gaitán. 5 de mayo de 1490. Fol.67r.

87 En Sevilla muchas cofradías también exigían el pago de una determinada cantidad de gallinas. Pérez González, S.M. 2005: 155-156.

88 Pérez González, S.M. 2005: 157-158. de los bienes de la citada María. Finalmente la Cofradía ganó el pleito por lo que el jurado dejó las 60 doblas en depósito a Pero Ferrández, jurado de San Dionís, quien debía pagarlas a la Hermandad cuando ésta otorgase carta de quitamiento cumplida y bastante en la dicha razón. ${ }^{89}$

Por lo que se refiere a las propiedades rurales hemos de decir que la documentación conservada es muy sintética al referirse a estas propiedades, pues suele omitir datos importantes como el tamaño, que es imposible de determinar a partir de la expresión empleada: un pedazo. ${ }^{90}$ Conocemos la extensión de cinco propiedades expresadas en aranzadas: media aranzada, ${ }^{91}$ una, ${ }^{92}$ dos y media ${ }^{93}$ y tres $^{94}$

En cuanto al tipo de explotación predominan las tierras dedicadas al cultivo de vid, ${ }^{95}$ lo que no es sorprendente dado el entorno rural en el que nos encontramos, ${ }^{96}$ en ocasiones combinada con arboleda, y al olivar. ${ }^{97}$ En algunos casos no podemos determinar el grupo al que pertenece, pues simplemente se hace referencia a una tierra. ${ }^{98}$

También conocemos la situación de varias de estas tierras. Algunas se localizan en los pagos como el de las Viñas, ${ }^{99}$ el de las Viñas de la Serrana ${ }^{100}$ y el del Olivar: ${ }^{101}$ otros se encontraban junto a caminos como el del rosal; ${ }^{102}$ o en matas como la del Olivar. ${ }^{103}$ Finalmente localizamos unas tierras en Guadabajaque. ${ }^{104}$

Con respecto al procedimiento por el que estas propiedades pasan a engrosar el patrimonio de las cofradías conocemos algún ejemplo de compra, como la aranzada de viña ${ }^{105}$ en la Serrana que la Hermandad de San Luis compró a Juan Salvador, hortelano, en nombre de su mujer Catalina Alfonso, por 400 maravedís que la Cofradía pagó en efectivo. ${ }^{106}$ Pero en otros casos no podemos determinar las vías de adquisición, puesto que la información la obtenemos de deslindes (Jimena Bernal, viuda de Gonzalo Ferrández, cirujano, vecina de la collación de San Marcos, vendió a Gonzalo

89 AMJFPN. Juan Martínez. 6 de agosto de 1414. Fol.201v.

90 AMJFPN. Juan Ortega Gaitán. 17 de abril de 1486. Fol.53r.

91 AMJFPN. Gonzalo Román. 11 de noviembre de 1470. Fol.70v.

92 AMJFPN. Juan Ortega Gaitán. 17 de abril de 1486. Fol.53r.; Juan Martínez. 21 de agosto de 1414. Fol.213r.

93 AMJFPN. Gonzalo Román. 10 de noviembre de 1470. Fol.69v.

94 AMJFPN. Juan Martínez. 28 de marzo de 1414. Fol.128v.

95 AMJFPN. Gonzalo Román. 10 de noviembre de 1470. Fol.69v.; Gonzalo Román. 11 de noviembre de 1470. Fol.70v. 11 de noviembre de 1470. Fol.70v. Juan Ortega Gaitán. 17 de abril de 1486. Fol.53r.

96 Bibliografía sobre la vid.

97 AMJFPN. Juan Martínez. 21 de agosto de 1414. Fol.213r.

98 Ídem.

99 AMJFPN. Juan Ortega Gaitán. 17 de abril de 1486. Fol.53r.

100 AMJFPN. Gonzalo Román. 11 de noviembre de 1470. Fol.70v. MARTÍN GUTIÉRREZ, E. 2004. La organización del paisaje rural durante la Baja Edad Media. El ejemplo de Jerez de la Frontera: 154. Sevilla: Universidad de Sevilla.

101 AMJFPN. Juan Martínez.. 21 de agosto de 1414. Fol.213r. Martín Gutiérrez, E. 2004: 167.

102 AMJFPN. Juan Martínez. 21 de agosto de 1414. Fol.213r. Martín Gutiérrez, E. 2004: 65.

103 AMJFPN. Juan Martínez. 21 de agosto de 1414. Fol.213r.

104 AMJFPN. Juan Martínez. 28 de marzo de 1414. Fol.128v. Situado en el camino entre Jerez de la Frontera y El Puerto de Santa María.

105 Borrero Fernández, M. 1991. "La viña en Andalucía durante la Baja Edad Media". Le vignoble d'Andalousie su Bas Mogen Âge. Onzièmes Journées Internationales. Abbaye de Flaran: 119-146. Flaran: Centre Culturel de l'Abbaye de Flaran.

106 AMJFPN. Gonzalo Román. 10 de noviembre de 1470. Fol.69v. 
Mateos de Medina un pedazo de tierras de una aranzada en la mata del olivar camino del rosal, que lindaba con olivar de la Cofradía de Santa María de San Lucas por 300 maravedís. ${ }^{107} \mathrm{O}$ el caso de Catalina Martínez, viuda de Benito Sánchez de Hinojosa, vecina de la collación de San Juan, que vendió a Gutierre López tres aranzadas de tierra calma en Guadabajaque que lindaban por tres partes con tierras de la Cofradía de Santa María, por tres doblas de oro moriscas mayores). ${ }^{108}$

Las cofradías no explotan directamente sus tierras, sino que prefieren arrendarlas para disponer de unas rentas fijas. El periodo de arrendamiento suele ser por una vida como lo ejemplifica la Cofradía de San Luis en la gestión de sus tierras. Tras protocolizar la compra de la aranzada de viña en la Serrana, acto seguido arrendó la mitad de la misma a Pero Martínez de Aguilar y a Leonor Ruiz, su mujer, por 400 maravedís anuales que habían de pagar por trimestres. ${ }^{109}$ Como puede comprobarse, en un año la Hermandad recuperaría el capital desembolsado para la adquisición de estas tierras. Y al día siguiente le arrendó al citado Pero Martínez de Aguilar la otra media aranzada de viña por un precio anual de 40 maravedís, habiendo de pagar la mitad en san Juan y la otra el primer día del año. ${ }^{110}$ Otro ejemplo lo intitula la Cofradía de San Sebastián que arrendó perpetuamente a Pero Jiménez Camacho un pedazo de tierra y viña ${ }^{111}$ de una aranzada en el Pago de las Viñas por 100 maravedís pagaderos el día de san Sebastián. ${ }^{112}$ Todos estos arrendamientos se hicieron mediante la firma directa del contrato entre la cofradía y el arrendatario.

Las rentas fijadas se pagaban en dinero estableciéndose como fecha de entrega de las mismas los trimestres del año o en una fecha señalada para la cofradía como el día de su patrón (el día de san Sebastián por la Cofradía de su nombre $)^{113}$ o de una fiesta señalada en el calendario agrícola (la mitad en san Juan y la otra el primer día del año). ${ }^{114}$

La cercanía del área rural jerezana a una importante ciudad comercial, así como el hecho de que su producción agrícola estuviese en gran medida controlada y dirigida desde la urbe, explica que en la misma el dinero fluía. Por ello no es de extrañar que la mayoría de las transacciones se hiciesen en dinero, como hemos podido comprobar en el análisis de los arrendamientos. Sin embargo el desarrollo de esta economía monetaria no fue paralelo a una expansión del volumen de metal acuñable en circulación y uso. ${ }^{115} \mathrm{~A}$ principios del siglo XVı las dificultades monetarias eran evidentes así como la falta de liquidez y los efectos de tal situación se evidencian claramente en el ámbito rural desde fines del

107 AMJFPN. Juan Martínez. 21 de agosto de 1414. Fol.213r.

108 AMJFPN. Juan Martínez. 28 de marzo de 1414. Fol.128v.

109 AMJFPN. Gonzalo Román. 10 de noviembre de 1470. Fol.69v.

110 AMJFPN. Gonzalo Román. 11 de noviembre de 1470. Fol.70v.

111 Borrero Fernández, M. 1998. “Protocolos Notariales y mundo rural. Los contratos agrarios como fuente para el estudio de la vida campesina en Andalucía Occidental entre el siglo xv y el xvı". En torno a la documentación notarial y a la historia: 83-96. Sevilla: Ilustre Colegio Notarial de Sevilla.

112 AMJFPN. Juan Ortega Gaitán. 17 de abril de 1486. Fol.53r.

113 Ídem.

114 AMJFPN. Gonzalo Román. 11 de noviembre de 1470. Fol.70v.

115 Borrero Fernández, M. 1986. "Efectos del cambio económico en el ámbito rural. Los sistemas de crédito en el campo sevillano (fines del siglo xv y principios del XvI". En la España medieval. V: 33. siglo xv y principios de la centuria siguiente. A ello hay que añadir las consecuencias que sufría el campo de unas crisis agrícolas intensas y una población diezmada por las epidemias, por lo que el esfuerzo por mantener unos niveles de producción mínimos eran grandes. Evidentemente la incidencia del fenómeno no fue igual para el campesinado que para el gran propietario.

Ese desarrollo de la economía monetaria no benefició de forma especial al campesinado, que sí se vio afectado por los resultados de la misma puesto que los precios subían y su poder adquisitivo se reducía. La necesidad de dinero la intentó paliar el campesino a través de distintas fórmulas. Una de ellas es la venta de tierras que ya hemos analizado. Pero además la dinámica de los nuevos principios económicos y la infiltración de la economía monetaria en el mundo rural determinó la aparición y desarrollo de nuevas fórmulas financieras. Nos estamos refiriendo a los sistemas de crédito.

Desde fines del siglo xv existían en el ámbito rural dos supuestos básicos para el desarrollo de los sistemas de crédito: el propietario que necesitaba dinero y el capitalista que deseaba hacer fructificar los ahorros monetarios de que disponía. En estos momentos la normativa de la Iglesia sobre la usura había sobrepasado ampliamente los límites establecidos por el Derecho canónico. El freno a cualquier operación de crédito era evidente, aunque ello no impidió el desarrollo de fórmulas financieras. En la época estudiada se van a poner en práctica medios indirectos para prestar dinero y recibir lo prestado en cantidad superior a través de la entrega diferida. ${ }^{116}$ Las primeras fórmulas de crédito fueron fórmulas de inversión de capitales que, con una función similar a la que los juristas denominan mutuo oneroso o préstamo con interés, no caían en la prohibición de la usura.

Una de estas fórmulas fue la compra de rentas. Se trataba de una operación según la cual un propietario vendía un censo o tributo perpetuo sobre sus bienes por una cierta cantidad de dinero. El proceso consistía en que un propietario necesitado de dinero suscribía un contrato similar a una compra-venta. El bien vendido era una parte de lo que rentaba la propiedad, que quedaba sujeta a perpetuidad a un canon anual que debía entregar al comprador. En la operación el propietario de la tierra conseguía la cantidad de dinero líquido que precisaba, mientras el comprador efectuaba una inversión de capital de la que iba a percibir anualmente unos ingresos, pero no la devolución del principal. La fórmula en sí misma no se puede considerar como un auténtico préstamo de capital, puesto que en éste se exigía el reembolso del capital en un tiempo determinado y en el caso de la compra de rentas el censatario o vendedor recibía el capital para siempre sin la obligación de devolverlo en un plazo concreto. ${ }^{117}$

Las cofradías decidieron invertir su capital a través de la fórmula de la compra de rentas. Un ejemplo puede servirnos para aclarar esta operación financiera. La Hermandad de San Luis compró a Juan Salvador, hortelano, en nombre de su mujer Catalina Alfonso, 138 maravedís de tributo

116 Se trata de medios simulados in fraudem usurae. Clavero Salvador, B. 1977. "Prohibición de la usura y constitución de rentas". Moneda y crédito 107-131.

117 De Almeida Costa, M.J. 1961. Raizes do censo consignativo. Para la historia do crédito medieval portugués: 78. Coimbra: Atlántica. 
perpetuo situado sobre dos aranzadas y media de tierra en la Serrana, por 1.400 maravedís a pagar cada año perpetuamente. ${ }^{118} \mathrm{El}$ hortelano recibió una cantidad de dinero que necesitaba, 1.400 maravedís, que pagaría a razón de 138 maravedís anuales a la Cofradía durante toda su vida. La misma inversión realizó la Cofradía de San Blas, aunque no podemos desarrollar el negocio pues la información que recibimos es indirecta. El jurado Manuel Fernández de Carmona, vecino de San Dionís, dejó en herencia a su hijo el jurado Pedro de Carmona el olivar de los alunados donde la Cofradía de San Blas tenía un tributo perpetuo de 160 maravedís. ${ }^{119}$ No podemos determinar el capital invertido de la Hermandad, tan sólo lo recaudado anualmente.

En ocasiones las cofradías fueron beneficiarias de estas compras de rentas mediante la donación del censo perpetuo que el donante cobraba por la operación de crédito realizada. De ello es bien ilustrativo el siguiente ejemplo: Antón de la Puerta, vecino de la collación de San Miguel, donó a la Cofradía de señor San Cristóbal 50 maravedís de censo perpetuo en unas casas en San Miguel en el callejón del portal, que pagaba cada año (hueco), viuda de Juan García, carpintero, el día de san Juan. ${ }^{120}$

El patrimonio cofrade se complementa con el capital artesanal. A pesar de que muchos de los cofrades estaban dedicados profesionalmente a la artesanía, ${ }^{121}$ las cofradías no contaron en su patrimonio con un número elevado de instalaciones donde desarrollar diversos oficios. Se limita a unas casas lagares que la Cofradía de San Blas poseía en la collación de San Mateo, sin que podamos determinar las condiciones de su explotación (por la Hermandad, por algún cofrade, en régimen de arrendamiento, etc.), puesto que la información la obtenemos a partir de la venta de unas casas en cuyo deslinde se menciona la citada instalación dedicada a la pisa de la uva. ${ }^{122}$ Esta casa lagar formaba parte de un amplio grupo de este tipo de edificio, muy extendido por toda la ciudad, tal como revela la documentación analizada para la realización del presente trabajo.

Una última vía de financiación de las hermandades fueron las limosnas. Suponemos que debieron ser mucho más abundantes de las que hemos documentado, pues sólo contamos con cuatro ejemplos. El Hospital de la Sangre recibió 50 maravedís por un lado ${ }^{123}$ y 100 maravedís por otro. ${ }^{124} \mathrm{La}$ Cofradía de San Bartolomé fue objeto de una donación de 10 maravedís ${ }^{125}$ y la de Santa María de Roncesvalles de tres maravedís. ${ }^{126}$ En estos dos últimos casos la ganancia obtenida fue del cien por cien, puesto que en ambas donaciones se solicita que los titulares de las cofradías intercedan y rueguen a Dios por el alma de los donantes.

118 AMJFPN. Gonzalo Román. 10 de noviembre de 1470. Fol.69v.

119 AMJFPN. Gonzalo Román. 26 de septiembre de 1471. Fol.423r.

120 AMJFPN. Bartolomé de Maya. 31 de julio de 1490. Fol.114r.

121 Sirva de ejemplo la junta de gobierno de la Cofradía de San Cristóbal: a Francisco López, espadero, hermano mayor, Juan Rodríguez, librero, Alfonso Gutiérrez, sastre, y Antón Gómez, borceguinero, alcalde (AMJFPN. Bartolomé de Maya. 7 de febrero de 1489. Fol.26v.).

122 AMJFPN. Juan Martínez. 4 de agosto de 1414. Fol.198v.

123 AMJFPN. Juan Ortega Gaitán. 16 de junio de 1490. Fol.101v.

124 AMJFPN. Bartolomé de Maya. 28 de marzo de 1490. Fol.63r.

125 AMJFPN. Juan Martínez. 10 de febrero de 1414. Fol.173v.

126 Ídem.
De acuerdo con la documentación estudiada, todo parece indicar que las limosnas no fueron una fuente importante de financiación de las cofradías debido a la escasez de las mismas. Las donaciones monetarias son muy puntuales y no muy abundantes. Ello nos lleva a pensar que la principal fuente de ingresos de las cofradías en la época estudiada fueron las rentas fijas generadas por las propiedades que hemos analizado. Tampoco hemos documentado, a diferencia del caso de Sevilla, ${ }^{127}$ otra vía de obtención de limosnas como la concesión de indulgencias. A cambio de la entrega de determinadas cantidades de dinero, las cofradías concedían estas gracias con las que ellas fueron favorecidas en el momento de su fundación por distintas autoridades eclesiásticas (papa, arzobispo, etc.). ${ }^{128}$ Dichas indulgencias eran divulgadas por determinadas personas a las que la cofradía encargaba este cometido. En el caso de Jerez de la Frontera ninguna de las cofradías estudiadas, siempre de acuerdo con la documentación analizada, gozaba de tales indulgencias.

\section{ACTIVIDADES BENÉFICO-ASISTENCIALES}

El centro de la actividad benéfico-asistencial desarrollada por las cofradías era su hospital. La mayoría de los hospitales medievales hasta el siglo xv fueron pequeños y funcionaron indistintamente como hospitales para curar enfermos, alberguerías para que los transeúntes pudiese allí pasar la noche y asilos para los ancianos. Además, atendiendo a su espíritu religioso y al igual que otras instituciones de esta naturaleza, gozaban de inmunidad frente a las autoridades no eclesiásticas y en ellos buscaban protección personas en distintas circunstancias.

El origen ${ }^{129}$ de los hospitales pertenecientes a las hermandades o cofradías es diverso. Por un lado, los que dependen de las cofradías de oficio surgieron del deseo y voluntad primordial de cada uno de ellos de contar con un centro propio donde realizar asistencia mutua, llevar a efecto sus cabildos y otros asuntos relacionados con su profesión, además de celebrar oficios religiosos.

Con las hermandades y cofradías de caridad ocurre algo parecido, creándose el hospital por el esfuerzo de los propios cofrades que compraban y levantaban la casa hospital. Muchos de estos cofrades eran personas modestas, con un profundo sentimiento religioso que los impulsaba a reunirse y fundar un hospital. En este sentido es un buen ejemplo la dedicación que demostraron los cofrades de Hermandad de

127 Pérez González, S.M. 2005: 167-168.

128 Pastor Torres, A. 2003. "Indulgencias y otras gracias espirituales de las Hermandades y Cofradías sevillanas a fines del siglo XVIII". Boletín de las Cofradías de Sevilla 529: 138-140; Pueyo Colomina, P. 2000. "Licencias para pedir limosnas, con o sin indulgencias, otorgadas por los arzobispos de la diócesis de Zaragoza en la segunda mitad del siglo XIV". Aragón en la Edad Media 16: 683-708; Riesco Terrero, A. "Documento del Papa Alejandro VI (a. 1493) otorgado a petición de los Reyes Católicos para regular en sus Reinos la concesión y predicación de indulgencias pontificias y cortar los abusos cometidos con motivo de la recaudación de limosnas y donativos ofrecidos por los agraciados". Hidalguía: la revista de genealogía, nobleza y armas 316-317: 503-520.

129 Carmona García, J. I. 1979. El sistema de la hospitalidad pública en la Sevilla del Antiguo Régimen: 55. Sevilla: Diputación Provincial. 
Santa María del Pilar, ${ }^{130}$ que se vieron envueltos en un pleito con unos vecinos con motivo de unas casas situadas junto al Hospital con las que querían y acoger más pobres.

Un tipo de fundación a caballo entre la iniciativa particular y la asociativa lo constituían aquellos legados de inmuebles hechos por personas individuales a cofradías con el fin de ser destinados a hospitales. De esta forma, aunque el peso de la marcha del centro recaía sobre la cofradía, la primitiva institución había sido particular, pero sólo a título de esfuerzo inicial y sin ninguna dote especial para su mantenimiento. Sería el caso de Hospital de Santa María que fue fundado por Gil de Hinojosa, Martín de Hinojosa y María Sánchez, su mujer, en 1362. Estaba destinado a recoger peregrinos mendigos a los que se les daba cama para dormir. ${ }^{131}$ Por tanto, el nuevo establecimiento surgía de la conjunción entre la donación particular y el interés de la cofradía por disponer de un hospital, el cual se levantaba en el inmueble que el particular proporcionaba a la cofradía para que pudiese tener su propio centro.

En cuanto a la tipología de los hospitales hemos de decir que la gran mayoría de las hermandades y cofradías estudiadas nacieron o acabaron siendo hermandades hospitalarias. Pero nunca debemos de perder de vista la definición que hemos dado de hospitales cumpliendo al mismo tiempo como tales, como alberguerías, o como asilos o, inclusive, como centro donde se reunía la hermandad, para realizar cualquier otro tipo de acción caritativa (limosnas, dotes de doncellas, entierros de pobres, etc.) o, por último, se dedicaban a otros fines que nada tenían que ver con la hospitalidad asistencial y sanitaria.

Podemos estudiar distintos tipos de hospitales en razón de su finalidad: $:^{132}$

a) Hospitales dependientes de cofradías profesionales o que reunían a personas de un mismo a oficio. A este grupo pertenecerían los hospitales de las corporaciones de oficios. Su única acción social caritativa la realizaban para con ellos mismos (asistencia mutua), socorriendo a sus compañeros en caso de enfermedad u otro impedimento, costeando funerales por los que fallecían, auxiliando a sus viudas e hijos, etc., no teniendo obligación de ejercer otro tipo de hospitalidad. Además en estos hospitales dependientes de cofradías artesanales se desarrollaban actividades propias del oficio.

b) Hospitales dependientes de hermandades con un fin benéfico-asistencial.

Se trata de centros asistenciales a través de los cuales las hermandades que los poseían ejercían la beneficencia. Podemos establecer una diferenciación en este tipo de asociaciones: las que tenían sus hospitales para celebrar actos religiosos y poner en práctica alguna que otra obra de caridad cristiana (no teniendo obligaciones asistenciales); y aquellas otras con fines benéficos, especialmente orientadas al recogimiento de pobres.

130 AMJFPN. Juan Román. 25 de noviembre de 1501. Fol.394v.

131 Sancho De Sopranis, H. 1973. Mariología medieval xericense: 56. Jerez: Centro de Estudios Históricos Jerezanos. Muñoz Y Gómez, A. 2010: 87-88.

132 Carmona García, J. I. 1979: 39.
Estos hospitales desarrollaban una práctica preferentemente religiosa-ceremonial, impulsadas por la cofradía respectiva bajo el influjo del santo patrón. Se distinguía claramente entre la hipotética hospitalidad que en base a su denominación de hospitales podrían estar obligados a realizar (que por el mandato de su fundación no caía dentro de sus objetivos) y aquella finalidad para la que habían sido instituidos.

En un segundo grupo se encontrarían aquellos centros que desarrollaban una acción benéfica-asistencial más definida. Carmona García ${ }^{133}$ habla de dotación de doncellas pobres, enterramiento de muertos o recogimiento de pobres.

El tipo de recogimiento más completo abarcaba el proporcionar casa, cama, ropa, repartir limosnas (por lo general durante las Pascuas), curar a los pobres si caían enfermos y enterrarlos si llegaban a morir, todo ello a costa del hospital. ${ }^{134}$

Para ello los hospitales de las hermandades recibieron una serie de donaciones destinadas a sufragar los gastos generados. Dichas donaciones se hacían a la institución en general o a personas particulares que están en ella acogidas:

1) adquisición de mobiliario y reparación del existente: camas $^{135}$ (mueble y complementos):

Catalina García, viuda de Benito Martín, vecina de la collación de El Salvador, mandó al Hospital de las hermanas de las candelas amarillas de la Hermandad de Santa María una manta, una almocela, un lenzuelo, ${ }^{136}$ porque rogasen a Dios por su alma. ${ }^{137}$

Catalina Alfonso la partera donó al Hospital de San Miguel un almadraque lleno de lana y su cama, ambos usados, para que durmiesen los pobres. ${ }^{138}$

Sancha Rodríguez, viuda de Juan García, vecina de la collación de San Dionís, mandó a la Hermandad de las hermanas de la Cofradía de Santa María de las candelas amarillas su cama de ropa porque rogasen a Dios por su alma. ${ }^{139}$

Ana Ferrández, mujer de Miguel Sánchez de la Puerta, vecina de la collación de San Miguel, mandó a la Hermandad de las hermanas de la Cofradía de Santa María de las candelas amarillas una sábana de estopa usada. ${ }^{140}$

Leonor Núñez, vecina de la collación de San Miguel, donó al Hospital de la Sangre de Jesucristo un almadraque grande, una sábana y una almohada. ${ }^{141}$

Queremos destacar las dos donaciones hechas a la Hermandad de las hermanas de la Cofradía de Santa

\footnotetext{
133 Ibídem: 44.

134 Ibídem: 47.

135 Abellán Pérez, J. 2011. El ajuar de las viviendas jerezanas en época de Isabel I de Castilla (1474-1504): 143-146. Cádiz: Universidad
} de Cádiz.

136 Abellán Pérez, J. 1993. La industria textil en Jerez de la Frontera (desde finales del siglo XIV a mediados del XV): 58-59. Jerez de la Frontera: Ayuntamiento de Jerez.

137 AMJFPN. Juan Martínez. 20 de marzo de 1414. Fol.112v.

138 AMJFPN. Juan Martínez. 3 de septiembre de 1448. Fol.110v.

139 AMJFPN. Juan Martínez. 28 de marzo de 1414. Fol.134v.

140 AMJFPN. Juan Martínez. 31 de marzo de 1414. Fol.141r.

141 AMJFPN. Juan Ortega Gaitán. 23 de noviembre de 1490. Fol.182r. 
María de las candelas amarillas, integrada exclusivamente por mujeres. El hecho de que contara con un hospital para atender al sector femenino de la sociedad jerezana finimedieval goza de una importancia singular, pues a fines de la Edad Media y hasta la conclusión del siglo XVI la cobertura hospitalaria de que gozaban las mujeres era muy escasa. De los 14 hospitales que existían en Jerez sólo el del Pilar curaba a mujeres de calenturas, el de San Pedro y el de Santa Catalina acogían a dos mujeres pobres, y el de la Concepción de San Marcos a mujeres ancianas. Es más, tras la reducción de finales del siglo XVI sólo quedó el de la Concepción. Más tarde el Hospital de la Sangre pasó a ocuparse de la curación de mujeres de todas las enfermedades y de la acogida de las transeúntes. ${ }^{142}$

2) limosnas en metálico para los pobres que se atienden en el hospital:

Catalina Fernández, mujer de Juan Sánchez, vecina en la collación de San Miguel, donó al Hospital de Santa María del Pilar 100 maravedís anuales detraídos de las rentas y lugares que ella poseía en sus casas de la collación de San Miguel. ${ }^{143}$

¿Son estas donaciones puramente altruistas? No. Pero lo que se pide a cambio es fácil de cumplir: rogar a Dios por el alma del donante. ${ }^{144}$

El hospital estaba atendido por los enfermeros u hospitalarios. El ejemplo más ilustrativo es el del Hospital de la Sangre y la donación hecha por Francisco de Hinojosa para dotarlo de un cuerpo de enfermos, recogida en una escritura otorgada el 12 de febrero de $1519 .{ }^{145}$ En ella establecía la entrega de unas tierras con cuyas rentas se contrataría a un matrimonio para que ejerciesen la labor de enfermeros encargados del cuidado y cura de los enfermos, así como las ordenanzas que debían cumplir. Éstas se referían a la limpieza del establecimiento (enfermería, letrinas, ropa de cama y mesa, las medidas higiénicas que habrían de dispensarse a los enfermos), la atención del enfermo que se hallaba in articulo mortis, y el cuidado espiritual de los enfermos (confesión, comunión, mantener encendida y limpia la lámpara que alumbraba el Santísimo Sacramento por parte de la enfermera, etc.).

En cuanto a la estructura de los hospitales, tan sólo conservamos descripciones y planos relativos al Hospital de la Sangre. ${ }^{146}$ De hecho el edificio se conserva actualmente en la calle Taxdirt ${ }^{147}$ y funciona como residencia de ancianos (Fundación Centro de acogida San José). Del resto poco o casi nada podemos aportar. Tan sólo afirmar que su tamaño, su estructura y capacidad asistencial estarían en proporción directa con la devoción de que era objeto la cofradía y sus

142 Serrano Pinteño, J. 2010-2012: 31-34.

143 AMJFPN. Juan Ortega Gaitán. 11 de junio de 1490. Fol.99v.

144 AMJFPN. Bartolomé de Maya. 4 de abril de 1489. Fol.55v.

145 Serrano Pinteño. J. 2010-21012: 11-12.

146 Serrano Pinteño. J. 2010-21012: 19: Construcción de las enfermerías; 20: Reparo de los corredores del camposanto; 30: Tasaciones de edificios; 35: Descripción del Hospital a fines del siglo xv; 47-49: Proyecto de Antón Martín Calafate, albañil y perito.

147 Antes llamada La Sangre: Cirera González, J.A. 2004: 87. titulares, pues de ello dependía el número y cantidad de donaciones percibidas.

Sobre la administración de estos hospitales hemos de decir que algunos tenían un patronazgo especial (el Hospital de Zurita por el pariente mayor de este linaje), mientras que la mayoría era responsabilidad directa de las cofradías. Por esta razón eran dirigidos y gobernados por sus propios cofrades, quienes nombraban a la persona responsable de la buena marcha del centro En ocasiones el cargo era ocupado mediante turnos por un período determinado.

Pero por encima de todos ellos se encontraba la acción vigilante y fiscalizadora de la jerarquía eclesiástica. La jurisdicción de ésta se extendía a todos los centros eclesiásticos, ya fuesen dirigidos por clérigos, ya a las cofradías, normalmente dirigidas por los laicos, pues también éstas debían recibir la visita del Ordinario (derecho de visita episcopal). Pero en la práctica las inspecciones de los visitadores eclesiásticos dejaron bastante que desear, tanto por su periodicidad como por su eficacia, dando lugar a una ausencia de control que permitiría una relajación total de la acción hospitalaria y benéfica.

El acompañamiento en los cortejos fúnebres y la celebración de sufragios pro remedio animae representa la segunda gran actividad benéfico-asistencial desarrollada por las cofradías. En primer lugar suponemos que la llevaron a cabo con sus cofrades, pues muchos capítulos de regla las obligaban a ello. Pero, sobre todo, hemos documentado un número importante de casos en los que una serie de personas, no pertenecientes a una determinada cofradía, se encomendaban a ella para que las enterrasen a cambio de cierta cantidad de dinero o de otro tipo de donación (bienes inmuebles, donación de rentas, propiedades rurales, etc.). Este predominio de referencias al entierro de los no cofrades se explica precisamente porque en el caso de los cofrades es un derecho inherente a su condición, que en los testamentos aparece a modo de recordatorio.

Precisamente es la vertiente económica de estos cultos lo que justifica su presencia en el conjunto documental estudiado: a cambio de ciertas celebraciones las cofradías incorporaron nuevos bienes a sus patrimonios, y tanto donante como receptor quisieron que su acuerdo, a fin de asegurar su cumplimiento, estuviese ratificado ante un escribano público. Estos encargos fueron fundamentales para la subsistencia de las cofradías por lo que recibían a cambio: casas, tierras, talleres, otros bienes generadores de rentas $y$, también, dinero en efectivo. Por ello debió haber en las cofradías un especial celo por cumplir con estas mandas testamentarias, por ofrecer una garantía de celebración de las mismas, en definitiva, por ganarse la confianza de posibles devotos que les aportarían nuevos bienes e ingresos.

La presencia de la muerte ${ }^{148}$ dominaba la vida cotidiana y la mentalidad del hombre de esta época. Ante ella tomaba una serie de actitudes, como las disposiciones testamentarias $^{149}$ y donaciones, legados y fundaciones de obras pías, con las que pretendían asegurarse su salvación mediante la preparación del "bien morir". Este auxilio de muerte también se buscaba en las cofradías. El hombre normal, vulgar, se aso-

148 Rubio García, L. y Rubio Hernansáenz, L. 2000. La mujer murciana en la Baja Edad Media: 133. Murcia: Universidad de Murcia.

149 Casamitjana I Vilaseca, J. 2004. El testamento en la Barcelona bajomedieval. La superación de la muerte patrimonial, social y espiritual. Pamplona: Eunsa. 
ciaba con otros, dando respuesta a la problemática del fin de la vida terrenal ${ }^{150}$ y de la existencia del más allá.

Pese al amplio arco cronológico que comprende nuestro estudio, el sentimiento que sus protagonistas muestran hacia la muerte en el espacio temporal indicado era el mismo, pues todos los testamentos responden a un mismo esquema y a un mismo sentimiento. ${ }^{151}$ La única diferencia radica en el número de disposiciones religiosas (misas, mandas, etc.).

La actuación frente a la muerte iba desde el imprescindible enterramiento del cadáver en una sepultura digna, hasta la celebración de sufragios por el alma del difunto. ${ }^{152}$ Es de resaltar que este comportamiento formaba parte de la acción benéfico-asistencial que la hermandad o cofradía desarrollaba, no solamente entre sus cofrades sino también entre los no cofrades, por lo cual su acción benéfica-asistencial no era particularista.

Vamos a analizar qué tipo de cultos se encargaban a las cofradías, quiénes confiaban a ellas sus últimas voluntades, y las que gozaban de mayor devoción a partir del número de cultos recibidos.

¿Quiénes eran las personas que confiaban a las cofradías la salvación de sus almas por medio de la celebración de distintos actos de cultos? Distinguimos entre cofrades y no cofrades. Podemos afirmar que de forma absolutamente mayoritaria, de acuerdo con la documentación estudiada, fueron particulares no vinculados a las cofradías los autores de estas mandas. Sobre un número total de 19 mandas 18 proceden de no cofrades frente a un cofrade. Los motivos que explican esta preeminencia de personas no pertenecientes a estas instituciones son los siguientes: los cofrades tenían unos derechos, adquiridos por su condición como tales, y sufragados con las distintas cuotas que estaban obligados a pagar. Confiaban en que su cofradía, que él integraba junto al resto de hermanos, se preocuparía y haría todo lo necesario para que su alma pasase el menor tiempo posible en el Purgatorio ${ }^{153}$ y llegase a alcanzar la gloria eterna. A pesar de ello, documentamos un cofrade entre los testadores, que analizamos más abajo.

Pero quienes no pertenecían a las cofradías, quienes carecían de este amparo institucional y, además, eran conscientes del mucho tiempo que pasarían purgando sus penas en el Purgatorio, se vieron en la necesidad de garantizar su futuro inmediato en la otra vida por medio del encargo expreso de una serie de celebraciones, cuya cantidad y

150 Mitre Fernández, E. 1999. “Actitudes del hombre ante la muerte". Historia, Sociedad, Cultura y Mentalidades: 31.: Bilbao: Servicio de Publicaciones de la Universidad del País Vasco.

151 Esta circunstancia es idéntica a la de otras ciudades y época. Véase García Guzmán, M.M. y Abellán Pérez, J. 1997. Y Sánchez Herrero, J. 1978: 326-328; 2001. "Vivir y morir en Estepa en el siglo XVII". Actas de las IV Jornadas sobre Historia de Estepa. La vicaría eclesiástica de Estepa: 239-283. Estepa: Ayuntamiento de Estepa.

152 Rubio Semper, A. 1994. "Piedad, Honras fúnebres y legados piadosos en Aragón (Calatayud) en la Baja Edad Media". Muerte, religiosidad y cultura popular: 241-277. Zaragoza: Instituto Fernando el Católico; Parejo Delgado, M. J. 1991. "Costumbres mortuorias recogidas en los testamentos ubetenses de fines de la Edad Media". Las ciudades andaluzas (Siglos XIII-XVI): 319-334. Málaga: Universidad de Málaga.

153 Le Goff, J. 1985. El nacimiento del Purgatorio. Madrid: Taurus; Mitre Fernández, E. 1994. "La muerte y sus discursos dominantes entre los siglos XIII y XV". Muerte, religiosidad y cultura popular: 26 y ss. Zaragoza: Instituto Fernando el Católico. cualidad estaba en proporción directa con la capacidad económica de cada uno: en principio, cuanto más próspera fuese la situación de una persona, mayor era el número de sufragios que podía encargar. Los que morían en gracia se salvaban, los que morían en pecado se condenaban. Pero los que morían en estado de gracia podían pasar un tiempo de pena en el Purgatorio, lo que podría también depender de los sufragios que por él se celebrasen. No obstante, siempre permanecía la justicia y la misericordia de Dios.

Pues bien, una serie de personas conscientes de que su vida como cristianos no había sido precisamente una imitación fiel del Evangelio y no habían seguido rigurosamente los mandatos de la Iglesia, encontraron o quisieron encontrar una ayuda a su pronto ingreso en el Paraíso en las cofradías. ${ }^{154}$ ¿Qué cofradías? Suponemos, la documentación no dice nada al respecto, que aquéllas por las que sentían especial devoción, las de su collación, las que gozaban de un reconocimiento general como buenas cumplidoras de mandas, etc. En la época estudiada las cofradías que recibieron un mayor número de encargos fueron las siguientes: ${ }^{155}$ Cofradía de la Misericordia (cuatro), Cofradía de la Sangre (cuatro), Cofradía de San Sebastián (cuatro), Cofradía de San Dionís (dos), Cofradía de Santa María (una), Cofradía de San Blas (una), Cofradía de Santa María de la iglesia de San Juan (una), Cofradía de San Francisco (una), y Cofradía de Santa María del Pilar (una).

La muerte se escenificaba en varios actos ${ }^{156}$ y el primero de ellos era la redacción de esa última voluntad ${ }^{157}$ que de forma mayoritaria tenía lugar cuando el fin se aproximaba. En el momento en que el deceso se sentía inmediato se requería los servicios de un escribano público, quien acudía a casa del moribundo para dar fe pública de sus últimas disposiciones recogidas en su testamento. Ésta era la norma general, aunque de ellas escapan algunas excepciones como el caso de Catalina Álvarez, cuyo testamento fue redactado por su marido tras su fallecimiento. ${ }^{158}$

Los testamentos incluyen dos tipos de disposiciones en las que se enmarcan las distintas mandas: unas religiosas (profesión de fe, ideas de temporalidad de la vida humana, la esperanza en la vida eterna, los medios para asegurarse la salvación) y otras de carácter material, dada la necesidad de que las últimas voluntades del testador se cumplieran estrictamente y su patrimonio se repartiese entre sus herederos. Tanto unas como otras quedaban confiadas a los albaceas.

Tras el fallecimiento la muerte salía del ámbito privado del hogar a un escenario público a través de un acto de especial significado social: el entierro. ${ }^{159} \mathrm{~A}$ diferencia de

154 Es lo que Mantecón denomina encomendarse, agregarse o acofradarse. Mantecón Rodríguez, T.A. 1990. Contrarreforma y religiosidad popular en Cantabria. Las cofradías religiosas: 93. Santander: Universidad de Cantabria.

155 Ordenadas de mayor a menor.

156 Gómez Nieto, L. 1991. "Actitudes femeninas ante la muerte en la Edad Media castellana". Religiosidad femenina: Expectativas y realidades (ss.VIII-XVIII): 63. Madrid: Asociación cultural Al-Mudayna.

157 García Fernández, M. 2003. “Vida y muerte en Valladolid. Un estudio de religiosidad popular y mentalidad colectiva: los testamentos". La religiosidad popular. Vida y muerte: la imaginación religiosa, v.2: 230. Barcelona: Anthropos.

158 AMJFPN. Juan Ortega Gaitán. 5 de julio de 1490. Fol.119r.

159 "Non the less, women of all ages were able to attend funerals and feasts that became such an important part of fraternity life. Such meetings helped to cement close female friendships" (Mate, M. E.. 1999. Women in Medieval English society: 64. Cambrige: University Press, 64). 
la costumbre actual que privatiza y a veces esconde casi todo lo relacionado con la muerte, hasta fechas recientes el entierro se convertía en el momento en que la persona se despedía de quienes hasta entonces habían mantenido con ella relaciones familiares, afectivas y de vecindad. ${ }^{160}$ También era el último recorrido por el entorno urbano que había sido el escenario de su existencia. Por ello, dependiendo de la capacidad económica, se intentaba envolver este acto previo antes de ser sepultado con el mayor boato y dotarlo de la más excelsa solemnidad.

En esa intención de emprender el último viaje con la mayor pompa costeable las cofradías tuvieron un protagonismo incuestionable. De hecho representa la segunda gran actividad benéfico-asistencial desarrollada por las cofradías después de las atenciones prestadas en sus hospitales. ${ }^{161}$ En primer lugar la llevaron a cabo con sus cofrades, pues muchos capítulos de regla las obligaban a ello, hasta el punto de que constituye una de las principales razones para ingresar en una de estas instituciones, tal como se evidencia en el elevado porcentaje de los capítulos de sus reglas que versan sobre esta temática. ${ }^{162}$ Sin embargo en ocasiones no estaba de más recordar esta obligación a las cofradías. De ello es buen ejemplo el testamento de Diego Ferrández, jurado, ${ }^{163}$ vecino de la collación de San Marcos, quien mandó en su testamento a la Cofradía de San Nicolás del Portal, donde era cofrade, le viniesen a hacer honra según la hacen a los cofrades y les dieran lo que su regla mandaba. ${ }^{164}$

Pero no sólo los cofrades requirieron la presencia de las cofradías en los cortejos fúnebres y enterramientos para el realce de los mismos. También lo hicieron un grupo de particulares no cofrades cuya capacidad económica les permitía pagar los servicios de las hermandades. Ellos formaban parte del grupo denominado encomendados, quienes contribuyeron de manera significativa a incrementar los ingresos cofrades. La participación de sus hermanos portando las candelas encendidas las convirtieron en elementos imprescindibles en todo entierro de cierta entidad. Especialmente impactante por lo nutrido de la comitiva debió ser el entierro de Catalina López, mujer de Nicolás Morón, vecina de la collación de Santiago, quien estableció en su testamento que en su cortejo fúnebre estuviesen presentes los Hospitales de la Misericordia, de la Sangre y de San Sebastián. ${ }^{165}$ Por su parte Juan Pérez Pezano, vecino de la collación de San Juan, solicitó que su cuerpo fuese acompañado a enterrar por los de la Misericordia y los de la Cofradía de San Sebastián. ${ }^{166}$ En las reglas de las cofradías se establece que todos los cofrades debían asistir al entierro de los encomendados, por lo que los cortejos

160 Todo lo dicho queda magníficamente ejemplificado en numerosas obras de arte como El entierro del Conde de Orgaz: Neumeyer, A. y Dieterich. A. 1982. El entierro del Conde Orgaz de El Greco. Madrid: Alianza Editorial.

161 "Las Cofradías eran verdaderas mutualidades de seguros de entierros". Sánchez Domínguez, P. Mujeres y cofradías en Málaga: 31. Málaga: Editorial Arguval.

162 Sánchez Herrero, J. y Pérez González, S.M. 2003.

163 Abellán Pérez, J. 1990. El Concejo de Jerez de la Frontera en la primera mitad del siglo Xv: 59-80. Jerez de la Frontera: Ayuntamiento de Jerez de la Frontera.

164 AMJFPN. Juan Martínez. 6 de agosto de 1414. Fol.201r.

165 AMJFPN. Juan Ortega Gaitán. 4 de agosto de 1490. Fol.143r.

166 AMJFPN. Bartolomé de Maya. 28 de marzo de 1490. Fol.63r. fúnebres de Catalina y Juan debieron ser bastante nutridos. De las 19 mandas recogidas 12 se refieren al acompañamiento del cadáver, siendo las cofradías encargadas las de San Sebastián (cuatro mandas), ${ }^{167}$ Misericordia (cuatro), ${ }^{168}$ San Dionís (dos), ${ }^{169}$ Santa María (una) ${ }^{170}$ y San Francisco (una). ${ }^{171}$

La documentación no es muy explícita en lo que se refiere al ritual desarrollado en estos acompañamientos del cadáver. Tanto en el caso de los cofrades como en el de los no cofrades sólo se menciona el acompañamiento del cuerpo desde la casa del difunto hasta el lugar elegido, iglesia o monasterio, para ser sepultado. Como hemos indicado los cofrades exigen que se les hagan las honras fúnebres propias de su condición, mientras que algunos no cofrades piden que los miembros de la cofradía estén presentes a dichas honras con sus candelas encendidas. ${ }^{172}$ Precisamente la donación que hacen a cambio de todo ello sirve en buena medida para costear la cera que se va a consumir.

La mayoría de los entierros solían pagarse en metálico dado que se trataba de un acto puntual que sólo se iba a celebrar una vez, a diferencia de los oficios pro remedio animae que se costeaban con propiedades generadoras de rentas para su celebración ad perpetuum. No había una cantidad estipulada, lo que puede ser indicativo de que, o bien las cofradías se conformaban con lo que cada persona tenía a bien pagar o, por el contrario, la fastuosidad (simple traslado del cuerpo o acompañamiento con candelas, rezos, enseres de la cofradía, etc.) de estas honras dependía de la cantidad pagada. La documentación no nos informa de ello, pero cabe pensar que se diese la segunda posibilidad (a más dinero, más celebración). Sea como fuere, las cantidades documentadas son 20 maravedís, ${ }^{173} 30$ maravedís, ${ }^{174} 200$ maravedís, ${ }^{175} 500$ maravedís, ${ }^{176}$ siendo la cantidad más alta de 6.000 maravedís pagados por Juana García la Melera a la Cofradía de la Misericordia de Jerez de la Frontera por acompañar su cuerpo a enterrar. ${ }^{177}$ En ocasiones se deja a criterio de una institución, de especial confianza para la testadora, el importe que habría de pagarse a la cofradía por el servicio funerario. Marina Sánchez ${ }^{178}$ pidió que la Cofradía de San Sebastián la acompañase a enterrar hasta prácticamente los límites de la ciudad,

167 AMJFPN. Bartolomé de Maya. 7 de febrero de 1489. Fol.26v.; 28 de marzo de 1490. Fol.63r.; Juan Ortega Gaitán.. 12 de abril de 1490. Fol.56r;.4 de agosto de 1490. Fol.143r.

168 AMJFPN. Bartolomé de Maya. 4 de abril de 1489. Fol.55v.; 28 de marzo de 1490. Fol.63r.; Juan Ortega Gaitán. Jueves 4 de agosto de 1490. Fol.143r.; 1 de octubre de 1490. Fol.147v.

169 AMJFPN. Juan Martínez. 11 de enero de 1414. Fol.12r.; 31 de octubre de 1414. Fol.259r.

170 AMJFPN. Bartolomé de Maya. 7 de febrero de 1489. Fol.26v.

171 AMJFPN. Juan Martínez. 13 de febrero de 1414. Fol.86r.

172 Juana González, hija de Alfonso González, vecina de San Dionís, manda a los cofrades de la Cofradía de San Dionís porque le vengan a honrar con las candelas de la Cofradía el día de su entierro estando su cuerpo presente 30 maravedís (AMJFPN. Juan Martínez. 31 de octubre de 1414. Fol.259r.).

173 AMJFPN. Juan Martínez. 11 de enero de 1414. Fol.12r.

174 AMJFPN. Juan Martínez. 13 de febrero de 1414. Fol.86r.; 31 de octubre de 1414. Fol.259r.

175 AMJFPN. Juan Ortega Gaitán. 5 de julio de 1490. Fol.119r.; Bartolomé de Maya. 28 de marzo de 1490. Fol.63r.

176 AMJFPN. Bartolomé de Maya. 28 de marzo de 1490. Fol.63r.

177 AMJFPN. Bartolomé de Maya. 4 de abril de 1489. Fol.55v.

178 AMJFPN. Bartolomé de Maya. 7 de febrero de 1489. Fol.26v. 
la Torrecilla, ${ }^{179}$ pues el lugar elegido para su eterno descanso fue el Monasterio de Santa María de la Defensión (La Cartuja) situado a una distancia considerable, para la época, del recinto urbano jerezano. Los padres cartujos se encargarían de pagar lo que considerasen oportuno a la Hermandad. Al margen de estos ejemplos parece ser que existía, de forma no oficialmente establecida, unas tasas por formar parte de los cortejos fúnebres. Así Catalina Alfonso, mujer de Gonzalo Pérez de Hita, mandó en su testamento que los hermanos del Hospital de San Sebastián acompañasen su cuerpo a su enterramiento y le diesen lo que es costumbre dar. ${ }^{180}$

En ocasiones los hospitales servían como lugar de enterramiento dado el carácter religioso de que gozaban. En el caso de Jerez de la Frontera fue el Hospital de la Sangre el que cumplió tal función. Tres fueron los testadores que solicitaron su entierro en esta institución: Catalina Martínez, mujer de Bartolomé Sánchez, vecina de la collación de San Mateo; ${ }^{181}$ Fernando González de Alba, vaquero, estante en Jerez; ${ }^{182}$ y Pero Jiménez Camacho, vecino de la collación de Santiago. ${ }^{183}$ El camposanto se encontraba en el claustro, cuyos corredores fueron reparados en $1577 .{ }^{184}$ Estaba junto a la iglesia, era de pequeño tamaño y contaba con pilares de cantería. En tres de sus lados tenía altares y en el cuarto una capilla dedicada a nuestra Señora de Belén, imagen dorada de bulto con el Niño Jesús en el brazo y colocada sobre un tabernáculo. Las paredes del claustro estaban decoradas con pinturas de temática desconocida.

Una vez depositado el cuerpo en la que sería su última morada, ${ }^{185}$ se iniciaba la serie de oficios de difuntos que el testador tuviera a bien encargar a cambio de la donación de ciertos bienes o el pago de una determinada cantidad en metálico. La mayoría de los testadores que confiaron a las cofradías la salvación de sus almas por medio de la celebración de distintos actos de culto fueron no cofrades, pues los cofrades confiaban en que su cofradía se preocuparía y haría todo lo necesario para que su alma pasase el menor tiempo posible en el Purgatorio y llegase a alcanzar la gloria eterna.

Dentro de las mandas referidas a los oficios de difuntos observamos un predominio casi absoluto de las grandes fiestas marianas que presentamos atendiendo a su fecha de celebración en el año litúrgico.

Una de las grandes fiestas era la de la Encarnación. Se celebra el 25 de marzo y puede ser contemplada desde una doble óptica, pues se trata de una fiesta tanto de Cristo, la Encarnación del Hijo de Dios, como de María, la Anunciación, aunque en la liturgia cristiana se celebra como

179 La Torrecilla era un antiguo cementerio que hubo en el Ejido jerezano, donde está hoy Madre de Dios y las calles Porvenir y Cartuja. Según Agustín Muñoz y Gómez tiene su origen en una construcción o torre que el cabecilla Abu Yusuf construyó cuando su asedio a Jerez en 1285, para divisar mejor las operaciones militares. (Muñoz Y Gómez. A. 2010: 343).

180 AMJFPN. Juan Ortega Gaitán. 12 de abril de 1490. Fol.56r. AMJFPN. Juan Ortega Gaitán. 4 de agosto de 1490. Fol.143r.

181 AMJFPN. Juan Ortega Gaitán. 7 de junio de 1490. Fol.95r.

182 AMJFPN. Juan Ortega Gaitán. 5 de julio de 1490. Fol.119r.

183 AMJFPN. Juan Ortega Gaitán 8 de julio de 1490. Fol.124r.

184 Serrano Pinteño, J. 2010-12: 20 y 36.

185 Bejarano Rubio, A. El hombre y la muerte. Testamento murcianos bajomedievales. Cartagena: Concejalía de Cultura. ROYER DE CARDINAL, S. 1987. Morir en España (Castilla Baja Edad Media). Buenos Aires: Universidad Católica. una fiesta mariana y desde esta perspectiva la estudiamos aquí. Su celebración fue encargada por Sancho Díaz, clérigo beneficiado de la iglesia de San Lucas, a la Cofradía de San Blas. ${ }^{186}$ En su testamento describe cómo quería que se llevase a cabo la celebración: sin sermón, en la iglesia de San Mateo por tres clérigos de otras iglesias que acompañasen a los de la citada parroquia. Cada clérigo cobraría 120 maravedís y todo se pagaría, incluidas las candelas y todo lo que fuere menester para la fiesta excepto los ornamentos.

Otras fiestas marianas citadas en la documentación son las de "Santa María de Agosto", la Asunción, la fiesta más antigua y más común en las celebraciones de la Iglesia cristiana, celebrada el 15 de agosto. ${ }^{187}$

Un oficio de difuntos demandado entre nuestros testadores son las remembranzas de difuntos (un recuerdo en forma de misa o responso). Normalmente se dejaba a criterio de la cofradía el lugar y fecha de celebración de la remembranza. ${ }^{188}$

En cuanto al lugar elegido por quienes encargaban a las cofradías los cultos pro remedio suae animae, en la mayoría de los casos no se especifica el mismo, ${ }^{189}$ por lo que suponemos que se dejaba a criterio de la cofradía designada la elección de la iglesia o monasterio donde habrían de celebrarse estos actos, sin olvidarnos, por supuesto, del propio hospital de la cofradía, que también debió ser escenario de ello y con frecuencia (simplemente por razones de comodidad). En dicha elección debieron primar criterios como la cercanía, la disponibilidad de horario en el lugar elegido y de ministros que presidiesen la ceremonia, las preferencias de los cofrades, etc.

Por lo que se refiere a la financiación de los oficios de difuntos, hemos de decir que la documentación parece evidenciar la no existencia de una normativa que estipulase la cantidad que había que pagar a las cofradías por la celebración de los oficios, sino que ésta era fijada por quienes hacían el encargo. Normalmente el pago no se efectuaba en dinero pues los testadores, a fin de garantizarse ad perpetuum la celebración de sus misas y fiestas cada año durante el tiempo, más o menos prolongado, que sus almas hubiesen de estar purgando sus culpas y pecados, preferían donarles ciertos bienes que generasen unas rentas fijas con las que sufragarlas. Estos bienes fueron: pagos procedentes de la compra de rentas ( 36 maravedís y 50 maravedís que se pagaban a la testadora de un censo perpetuo; ${ }^{190} 1000$ maravedís para siempre jamás de los censos que el testador tenía en El Puerto de Santa María para la celebración anual y perpetua de una fiesta de la Encarnación) $)^{191}$ y alquileres de casas (100 maravedís anuales detraídos de las rentas y

186 AMJFPN. Bartolomé de Maya. 5 de mayo de 1489. Fol.81v.

187 Marina Sánchez encargó celebrar a la Cofradía de Santa María una misa de réquiem cantada el día de Santa María de agosto (AMJFPN. Bartolomé de Maya. 7 de febrero de 1489. Fol.26v.)

188 Sancho Díaz, clérigo beneficiado de la iglesia de San Lucas, manda que el Hospital de Santa María de la iglesia de San Juan celebre unas remembranzas según Mari García lo estableció en su testamento (AMJFPN. Bartolomé de Maya. 5 de mayo de 1489. Fol.81v.).

189 La excepción la constituye Catalina Fernández, mujer de Juan Sánchez, vecina en la collación de San Miguel, quien mandó al Hospital de Santa María del Pilar la celebración de una fiesta anual de nuestra señora santa María en la iglesia de San Miguel (AMJFPN. Juan Ortega Gaitán. 11 de junio de 1490. Fol.99v.).

190 AMJFPN. Bartolomé de Maya. 7 de febrero de 1489. Fol.26v.

191 AMJFPN. Bartolomé de Maya. 5 de mayo de 1489. Fol.81v. 
lugares que la testadora poseía en sus casas de la collación de San Miguel, por la celebración de una fiesta anual de nuestra señora santa María en la iglesia de San Miguel). ${ }^{192}$

Como puede observarse existe entre las donaciones un predominio de las rentas en metálico cuya recepción se establece perpetuamente para jamás, lo que que aseguraría, al menos teóricamente, el cumplimiento ad perpetuum de las disposiciones de quienes las donaban.

Finalmente, algunas personas sólo pidieron a las cofradías a las que se encomendaban que los pobres del hospital rogasen por sus almas. ${ }^{193}$

\section{CONCLUSIONES}

El estudio de las hermandades y cofradías jerezanas a fines de la Edad Media, a partir de la documentación constituida por los Protocolos notariales, nos ha permitido construir algunas piezas de ese complejo puzzle que constituye el origen de estas instituciones en la Andalucía finimedieval. Hemos podido dar respuesta al interrogante planteado en trabajos anteriores sobre la prioridad en el nacimiento entre el hospital y la cofradía, dado que todas las corporaciones estudiadas y de acuerdo con las definiciones dadas tenía la doble vertiente de asociaciones dedicadas a actividades benéfico-asistenciales y culturales. Hemos documentado casos muy ilustrativos sobre el nacimiento de hospitales a los que luego se asocia una cofradía, así como otros ejemplos de instituciones cofrades que luego adoptan funciones hospitalarias, teniendo siempre en cuenta la descripción realizada sobre lo que era un hospital en la época estudiada. Cada uno de los casos analizados pormenorizadamente ejemplifican lo afirmado.

Queremos destacar, al amparo de una corriente historiográfica relativamente reciente pero ya bastante consolidada, los estudios sobre la mujer, el hallazgo de una cofradías integrada exclusivamente por miembros del sector femenino de la población jerezana, la Hermandad de Santa María de las candelas amarillas. $Y$ en lo que se refiere al órgano gubernativo de estas instituciones la presencia de una priosta, sin que podamos determinar si lo era de la citada Cofradía o de otra. En cualquier caso la importancia del dato radica en las condiciones de práctica igualdad de la que gozaron las mujeres en el seno de estas corporaciones así como en los derechos de que gozaron.

Las cofradías jerezanas de finales de la Edad Media estaban plenamente insertas en los mecanismos que articulaban la economía de la ciudad. Dentro de su patrimonio figuraban bienes inmuebles, propiedades rurales e instalaciones artesanales, patrimonio que supieron explotar de acuerdo con las condiciones de un mercado que conocían perfectamente y con el objetivo de costear las actividades que constituían la razón de su existencia. Al mismo tiempo algunas de estas hermandades se vieron muy bien posicionada en la nueva economía monetaria que se desarrolla en las ciudades andaluzas a fines de la Edad Media y que alcanzó en sus consecuencias al ámbito rural dependiente de estos centros urbanos. De esta forma aquellas cofradías

192 AMJFPN. Juan Ortega Gaitán. 11 de junio de 1490. Fol.99v.

193 Juana García la melera manda en su testamento que los pobres del Hospital de la Misericordia recen por su alma (AMJFPN. Bartolomé de Maya. 4 de abril de 1489. Fol.55v.). que contaban con el capital líquido necesario participaron en actividades de créditos que les proporcionaron pingües beneficios, evitando caer en la condenada usura.

Sin duda, las cofradías fueron las instituciones que desplegaron una mayor y más intensa actividad asistencial entre los vecinos del Jerez de finales del siglo $\mathrm{xV}$ y principios del XVI. Cofrades o no cofrades, quienes gozaban de una situación soioeconómica desahogada acudieron a ellas para que los atendieran en su tránsito a la gloria eterna. Solicitaron sus servicios en la vela antes del abandonar la vida terrena, en los cortejos fúnebres, en los oficios de difuntos que habían de acortar el tiempo de purgación de las faltas cometidas. Así lo dejaron establecido en sus testamentos, al que convirtieron en el garante de su salvación para evitar las penas eternas. En estas últimas voluntades un aspecto positivo de la muerte pues no hay referencias al infierno o al Purgatorio, sino que hay plena confianza en el tránsito a la vida eterna en el que las cofradías son agentes de especial importancia. No obstante da la impresión de que el fenómeno cofrade está aún en ciernes y prueba de ello es que, a diferencia de Sevilla, se prefiere que los diferentes clérigos de las parroquias se encarguen de la celebración de los oficios de difuntos.

Aún son muchos los interrogantes que quedan por responder y mucha la luz con la que alumbrar sobre el conocimiento de las hermandades y cofradías de finales de la Edad Media. Confiamos en que la continuación en el estudio de la documentación nos permita dar respuestas y alumbrar los muchos secretos que aun guardan estas instituciones, cuyo protagonismo en la vida de los hombres que contemplaron el paso de la Medievalidad a la Edad Moderno queda fuera de todo debate.

\section{BIBLIOGRAFÍA}

Abellán Pérez, J. 1990. El Concejo de Jerez de la Frontera en la primera mitad del siglo xv: 59-80. Jerez de la Frontera: Ayuntamiento de Jerez de la Frontera.

Abellán Pérez, J. 1993. La industria textil en Jerez de la Frontera (desde finales del siglo XIV a mediados del $X V$ ). Jerez de la Frontera: Ayuntamiento de Jerez.

Abellán Pérez, J. 2011. El ajuar de las viviendas jerezanas en época de Isabel I de Castilla (1474-1504). Cádiz: Universidad de Cádiz.

Arboleda Goldaracena, J.C. 2012. "La devoción a la Sangre de Cristo y el origen de las cofradías penitenciales a fines de la Edad Media: el caso de la ciudad de Málaga. Revista de Historia Autónoma 1: 73-88.

Arboleda Goldaracena, J. C. 2012. "El gobierno de las hermandades y cofradías andaluzas en la Baja Edad Media”, en Arízaga Bolumburu, B. et alii (eds.), Mundos medievales: espacios, sociedades y poder. Homenaje al Prof. José Ángel García de Cortázar, t. II: 1005-1014. Santander: Universidad de Cantabria.

Aurell, J. y Pavón, J. (Coords.). 2002. Ante la muerte: Actitudes, formas y espacios en la España medieval. Pamplona: Eunsa.

Barron, C. 1985. "The Parish Fraternities of Medieval London". The Church in Pre-Reformation Society: 13-37. Woodbridge: The Boydell Press.

Bejarano Rubio, A. El hombre y la muerte. Testamento murcianos bejomedievales. Cartagena: Concejalía de Cultura.

Bono, J. 1979-1982. Historia del Derecho Notarial Español. Madrid: Junta de Decanos de los colegios notariales de España.

Borrero Fernández, M. 1986. "Efectos del cambio económico en el ámbito rural. Los sistemas de crédito en el campo sevillano (fines del siglo xv y principios del XVI". En la España medieval. V: 219-244.

Borrero Fernández, M. 1991. "La viña en Andalucía durante la Baja Edad Media”. (Le vignoble d’Andalousie su Bas Mogen Âge). Onzièmes Journées Internationales. Abbaye de Flaran: 119-146. Flaran: Centre Culturel de l'Abbaye de Flaran. 
Borrero Fernández, M. 1998. "Protocolos Notariales y mundo rural. Los contratos agrarios como fuente para el estudio de la vida campesina en Andalucía Occidental entre el siglo XV y el XVI". En torno a la documentación notarial y a la historia: 83-96. Sevilla: Ilustre Colegio Notarial de Sevilla.

Carlé, M.C. 1993. Una sociedad del siglo xv: Los castellanos en sus testamentos. Buenos Aires: Universidad Católica de Argentina.

Caro Cancela, D. (Coord.) 1999. Historia de Jerez de la Frontera. De los orígenes a la época medieval: 261-350. Cádiz: Diputación de Cádiz.

Casamitjana I Vilaseca, J. 2004. El testamento en la Barcelona bajomedieval. La superación de la muerte patrimonial, social y espiritual. Pamplona: Eunsa.

Casquero Fernández, J. A. 1997. "La religiosidad de las mujeres: las cofradías de Santa Águeda en la diócesis de Zamora, siglos XVIIXIX". Religiosidad popular en España: 57-80. V. I. Madrid: Estudios Superiores de El Escorial.

Castro, A. 2002. Historia de Jerez de la Frontera. Sevilla: Editorial Renacimiento.

Cirera González, J.A. 2004. Calles jerezanas que fueron conocidas por otros nombres en el siglo XX. Jerez de la Frontera: Ediciones AE.

Clavero Salvador, B. 1977. "Prohibición de la usura y constitución de rentas". Moneda y crédito: 107-131.

Carmona García, J. I. 1979. El sistema de la hospitalidad pública en la Sevilla del Antiguo Régimen. Sevilla: Diputación Provincial.

Collantes de Terán Sánchez, A. 2007. "Los centros urbanos andaluces de la frontera con Granada". Jornadas de Historia de Lucena: 41-66. Lucena: Excelentísimo Ayuntamiento.

De Almeida Costa, M.J. 1961. Raizes do censo consignativo. Para la historia do crédito medieval portugués: 78. Coimbra: Atlántica.

García Fernández, M. 2003. "Vida y muerte en Valladolid. Un estudio de religiosidad popular y mentalidad colectiva: los testamentos". La religiosidad popular. Vida y muerte: la imaginación religiosa, v.2: 224-243. Barcelona: Anthropos.

García Guzmán, M. M. y Abellán Pérez. J. 1997. La religiosidad de los jerezanos según sus testamentos (siglo Xv). Cádiz: Agrija Ediciones.

García Herrero, M.C. 1990. Las mujeres en Zaragoza en el siglo XV. Zaragoza: Ayuntamiento de Zaragoza.

Gómez Nieto, L. 1991. "Actitudes femeninas ante la muerte en la Edad Media castellana". Religiosidad femenina: Expectativas y realidades (ss. VIII-XVIII): 63. Madrid: Asociación Cultural Al-Mudayna.

Le Goff, J. 1985. El nacimiento del Purgatorio. Madrid: Taurus.

Mantecón Rodríguez, T.A. 1990. Contrarreforma y religiosidad popular en Cantabria. Las cofradías religiosas. Santander: Universidad de Cantabria

Mariscal Trujillo, A. 2003. Por las calles del viejo Jerez. Jerez de la Frontera: Ediciones Jerezanas.

Martín Gutiérrez, E. 2004. La organización del paisaje rural durante la Baja Edad Media. El ejemplo de Jerez de la Frontera. Sevilla: Universidad de Sevilla.

Martín-Viveros Tajuelo, A. 2012. "Las cofradías castellanas en la Edad Media. Pasado, presente y futuro de la producción historiográfica", Espacio, Tiempo y Forma. Serie III: Historia Medieval 25: 285-307.

Mate, M. E. 1999. Women in Medieval English society. Cambrige: University Press.

Meersseman, G.G. 1977. Ordo fraternitatis. Confraternite e pietá dei laici nel Medioevo. Roma: Herder Editrice e Librería.

Mitre Fernández, E. 1994. "La muerte y sus discursos dominantes entre los siglos XIII y XV". Muerte, religiosidad y cultura popular: 15-34. Zaragoza: Instituto Fernando el Católico.

Mitre Fernández, E. 1999. "Actitudes del hombre ante la muerte". Historia, Sociedad, Cultura y Mentalidades: 25-36. Bilbao: Servicio de Publicaciones de la Universidad del País Vasco.

Neumeyer, A. y Dieterich. A. 1982. El entierro del Conde Orgaz de El Greco. Madrid: Alianza Editorial.

Parejo Delgado, M. J. 1991. "Costumbres mortuorias recogidas en los testamentos ubetenses de fines de la Edad Media". Las ciudades andaluzas (Siglos XIII-XVI): 319-334. Málaga: Universidad de Málaga.

Pastor Torres, A. 2003. "Indulgencias y otras gracias espirituales de las Hermandades y Cofradías sevillanas a fines del siglo XVIII". Boletín de las Cofradías de Sevilla 529: 138-140.
Pérez González, S.M. 2005. Los laicos en la Sevilla bajomedieval: Sus devociones y cofradías: 115-274. Huelva: Servicio de Publicaciones de la Universidad de Huelva.

Pérez González, S.M. 2012. "De la tipificación a la realidad documentada: Las jerezanas a fines de la Edad media (1392-1505)". Religiosidad Sevilla: Homenaje al profesor Sánchez Herrero: 421452. Sevilla: Aconcagua Libros.

Pueyo Colomina, P. 2000. "Licencias para pedir limosnas, con o sin indulgencias, otorgadas por los arzobispos de la diócesis de Zaragoza en la segunda mitad del siglo XIV". Aragón en la Edad Media 16: 683-708.

Repetto Betes, J.L. (Coord.). 1995. La Semana Santa de Jerez y sus cofradías. Jerez de la Frontera: Ayuntamiento de Jerez.

Riera Vayreda, F. 1997. "La Cofradía de la Sangre del Hospital General de Mallorca". Memoria Ecclesiae 11: 505-511.

Riesco Terrero, A. "Documento del Papa Alejandro VI (a. 1493) otorgado a petición de los Reyes Católicos para regular en sus Reinos la concesión y predicación de indulgencias pontificias y cortar los abusos cometidos con motivo de la recaudación de limosnas y donativos ofrecidos por los agraciados". Hidalguía: la revista de genealogía, nobleza y armas 316-317: 503-520.

Rojas Vaca, M. D. 1998. Un registro notarial de Jerez de la Frontera (Lope Martínez, 1392). Madrid: Fundación Matritense del Notariado.

Rosser, G. 1990. "The Essence of Medieval Urban Communities: the Vill of Westminster, 1200-1540". The Medieval Town: 216-237. London.

Royer De Cardinal, S. 1987. Morir en España (Castilla Baja Edad Media). Buenos Aires: Universidad Católica.

Rubio García, L. y Rubio Hernansáenz, L. 2000. La mujer murciana en la Baja Edad Media. Murcia: Universidad de Murcia.

Rubio Semper, A. 1994. "Piedad, Honras fúnebres y legados piadosos en Aragón (Calatayud) en la Baja Edad Media”. Muerte, religiosidad y cultura popular: 241-277. Zaragoza: Instituto Fernando el Católico.

Sánchez Domínguez, P. Mujeres y cofradías en Málaga. Málaga: Editorial Arguval.

Sánchez Herrero, J. 1978. Las diócesis del Reino de León. León: Colección "Fuentes y Estudios de Historia Leonesa", no 20.

Sánchez Herrero, J. 2001. "Vivir y morir en Estepa en el siglo XVII". Actas de las IV Jornadas sobre Historia de Estepa. La vicaría eclesiástica de Estepa: 239-283. Estepa: Ayuntamiento de Estepa.

Sánchez Herrero, J. 1988. "Las Cofradías de Semana Santa de Sevilla durante la Modernidad. Siglos XV a XVII". Las Cofradías de Sevilla en la Modernidad: 29-97. Sevilla: Universidad de Sevilla.

Sánchez Herrero, J. 1996. "El origen de las cofradías de Semana Santa o de Pasión en la Península Ibérica": Temas Medievales 6: 31-79.

Sánchez Herrero, J. 1999. "La evolución de las Hermandades y Cofradías desde sus momentos fundacionales a nuestros días". I Congreso Internacional de Hermandades y Religiosidad Popular: 29-53. Sevilla: Fundación El Monte.

Sánchez Herrero, J. y Pérez González, S.M. 1999. "La devoción a la Preciosa Sangre de Cristo de Sevilla: La importancia de la devoción a la preciosa sangre de Cristo en el desarrollo de la devoción y la imaginería de la Semana Santa". Aragón en la Edad Media 14-15: 1429-1452.

Sánchez Herrero, J. y Pérez González, S.M. 2003. CXIX Reglas de cofradías y hermandades andaluzas. Siglos XIV, XV y XVI. Huelva: Servicio de Publicaciones de la Universidad de Huelva.

Sancho de Sopranis, H. 1929. "Diego Fernández de Zurita, alcalde de Arcos, embajador en Granada" Revista de Historia y de Genealogía Española, 2o época, III: 11-42, 107-116, 326-337.

Sancho de Sopranis, H. 1964-1969. Historia de Jerez de la Frontera desde su incorporación a los dominios cristianos. Jerez: Jerez Industrial

Sancho de Sopranis, H. 1973. Mariología medieval xericense. Jerez: Centro de Estudios Históricos Jerezanos.

Serrano Pinteño, J, 2004. "Reformas barrocas en el Hospital de la Sangre de Jerez de la Frontera: Juan Díaz de la Guerra y Rodrigo de Alva". Revista de Historia de Jerez 10: 105-112

Serrano Pinteño, J. 2010-2012 “El Hospital de la Sangre. De la fundación a la reducción de 1636. Nuevos datos". Revista de Historia de Jerez 16-17: 1-49

Vauchez, A. 1987. Les laïcs au Moyen Age. Pratiques et experiénces religieuses: 95-96. Paris: Les éditions du cerf. 